


\author{
University of São Paulo \\ Ribeirão Preto Medical School
}

Priscilla Carnavale Gomes Ferreira

Splenic function and cellular adhesion events in Sickle Cell Anemia and in Hereditary

Spherocytosis

Ribeirão Preto

2018 


\section{PRISCILLA CARNAVALE GOMES FERREIRA}

Splenic function and cellular adhesion events in Sickle Cell Anemia and in Hereditary Spherocytosis

Thesis presented to the Ribeirão Preto Medical School of the University of São Paulo for obtention of the PhD degree in Sciences.

Program: Clinical Oncology, Stem Cells and Cell Therapy.

Area of Concentration: Stem Cells and Cell Therapy.

Advisor: Prof. Dr. Dimas Tadeu Covas

Ribeirão Preto 
Autorizo a reprodução e divulgação total ou parcial deste trabalho, por qualquer meio convencional ou eletrônico, para fins de estudo e pesquisa, desde que citada a fonte.

Ferreira, Priscilla Carnavale Gomes

Função esplênica e eventos de adesão celular em Anemia Falciforme e em Esferocitose Hereditária. Ribeirão Preto, 2018.

77 p. : il. ; $30 \mathrm{~cm}$

Tese de Doutorado apresentada à Faculdade de Medicina de Ribeirão Preto / USP. Área de concentraçã: Células-Tronco e Terapia Celular.

Orientador: Covas, Dimas Tadeu.

1. Anemia Falciforme. 2. Função Esplênica.

3. Reticulócitos. 4. Adesão Celular.

5. Baço. 6. Esferocitose Hereditária. 
Name: FERREIRA, Priscilla Carnavale Gomes

Title: Splenic function and cellular adhesion events in Sickle Cell Anemia and in Hereditary Spherocytosis.

\author{
Thesis presented to the Ribeirão Preto \\ Medical School of the University of São \\ Paulo for obtention of the degree of PhD in \\ Sciences.
}

Approved in:

\title{
Examination Board
}

Prof. Dr. Institution:

Judgment: Signature:

Prof. Dr. Institution:

Judgment: Signature:

Prof. Dr. Institution:

Judgment: Signature:

Prof. Dr. Institution:

Judgment: Signature:

Prof. Dr. Institution:

Judgment: Signature: 
To those who have always been by my side, supporting me unconditionally in the moments of calm and storm. 
I would like to thank Prof. Dr. Dimas Tadeu Covas, for having accepted me at the Post-Graduation Program as a PhD student, for having allowed me to develop this work at the Hemocentro of Ribeirão Preto and for having provided me the opportunity to join the Franco-Brazilian collaboration established.

I especially thank Prof. Dr. Ana Cristina Silva Pinto, for the indispensable orientation in the clinical part of the project, for the constant support and for the confidence in me. I also thank Dr. Yann Lamarrey for the valuable support and camaraderie in the last stage of the project.

My sincere thanks also go to Prof. Dr. Jacques Elion, Prof. Dr. Wassim E[ Nemer and Prof. Dr. Caroline Le Van Kim from the Institut National de la Transfusion Sanguine - INTS, Paris, France, who have welcomed me in their team as intern for a mission and who have given access to their laboratory and research facilities. Also, I thank them for the valuable teachings shared, for the always pleasant conviviality and the willingness to help me in the intellectual part of the project.

To the dear colleagues of the INTS, Claudine Lapouméroulie, Mickaël Marin, Cátia Pereira and Jean-Philippe Semblat for the pleasant camaraderie and the indispensable assistance on the Adhesion Platform and on the Flow Cytometry protocol for this work. Thanks also to Prof. Dr. Thierry Peyrard for helping with the protocol of 6lood sample freezing and thawing, as well as for the material provided.

Special thanks go to Prof. Dr. Maristela Orellana, for welcoming me at the Cell Therapy Laboratory so that I could be introduced to the Cell Culture and Therapy research field, for providing my learning in a very important part of the laboratory conducts and concepts that I have mastered, and especially for the friendship and trust that have been 
created over the years. Thanks also to the colleagues Aline Garcia, Thais Siqueira and Karina Alves for the conviviality and help whenever I needed.

I also thank my dear working partners and friends Sâmia Caruso and Taísa Fernandes, for the crucial support with the Adhesion Platform experiments, for the exchange of knowledge and experience, for the fun moments and for the unconditional support in difficult times. I am also very grateful to my fellow labmates and friends Juliana Veda, Lílian Figueiredo and Jenny Manzaro. You were all essential for making my walk, lighter. Thank you for the talks, for the moments of shared joy and anguish.

Thanks to Patricia Palma and Camila Menezes of the Flow Cytometry Laboratory, for the processing and analysis of this work's blood samples and for the camaraderie of so many years. Thanks to $\mathcal{N} a t a l i a$ Aydar and to Carmen Simão for the help and sympathy.

I also thankJosiane Serrano, Maria Rosa Arcodepani, Ícaro Greggio and Dr. Danielle Magalhães for the friendship and for all the support dispensed.

To the Reception secretaries and to the Outpatient Clinic Staff of the Hemocentro of Ribeirão Preto I give my thanks, especially to Terezinha, Sara and the nurses Paola, Lucimara, Poliana, Bruna, Viviane, Carolina, Liliana, Juliana, Tereza, Sandra, Livia, Thiago and Luciana for the valuable help in the collection of patients' 6lood samples and for the camaraderie. Thanks to Dr. Giuliana Dotoli and the other hematologists of the Outpatient Clinic for helping with the patients' medical records.

I would like to give special thanks to the patients who have agreed to participate voluntarify in this work, contributing honorably to science. 
To all the employees of the Hemocentro of Ribeirão Preto, for the pleasant daily conviviality. Especially the cleaning staff André, Marcos, Lucia, Nice, Alice and Cristina for the talks, often at alternate work schedules.

To Adriana Fuzaro, post-graduation secretary of the Clinical Oncology, Stem Cell and Cell Therapy Program for the support and explanations provided throughout the doctoral course.

To dear Dalvinha Catto for the help, efficiency and affection dispensed during this period. To the library secretary, Marjory Donato, for having always been helpful in the search of books and papers.

To CNNPq, for the financial support granted.

My thanks also goes to Prof. Dr. Maria Luisa Paçó Larson, Prof. Dr. Enilza Maria Espreafico, Prof. Dr. Ricardo Guelerman Pinheiro Ramos and Prof. Dr. Rafael Silva Rocha for having accepted me as mentors at the discipline "Cellular and Molecular Biology, Histology and Embriology" of the Medicine graduation course for the Supervised Internship in Teaching Program - PAE. It has contributed a lot for my teaching skills on higher education.

I would like to thank the thesis committee members for the availability in contributing with their experience to this work and for their valuable suggestions and support.

I thank the dear friends I have made over all these years at the Hemocentro, Aline Bonfim, Amanda Mizukami, Carolina Caliari, Florencia Tellechea, Luiza Junqueira, Marcela Faria and Rafael Biagio, and the other colleagues of the Laboratory of Functional Biology, the Laboratory of Biotechnology, the Laboratory of Cell Culture and the Laboratory 
of Molecular Biology. Also, thanks to Prof. Dr. Simone Kashima, for having intermediated and supported the practical issues of my doctorate.

Finally, I would like to immensely thank my family. Words cannot express how grateful I am to my husband Flávio, to my mother Edna and to my sister Caroline for the unconditional love you have given and for all of the sacrifices that you've made on my behalf. Your prayer and your support for me have been what have sustained me thus far and made me strive towards my goal after all. I also thank my father Ronaldo, my aunt Antônia and my brother-in-law Yazan. I want to express special appreciation to my beloved husband who has spent sleepless nights with me and has always been my support in the moments when there was no one to answer my queries. Thank you for being my safe harbor, for loving me and for taking care of me.

Still, I thank God for blessing and guiding my path and for giving me health and willingness to move on, always. 
Nothing lasts forever, neither pain nor joy. Everything in life is learning. Everything in life is overcome. 


\section{RESUMO}

FERREIRA, P. C. G. Função esplênica e eventos de adesão celular em Anemia Falciforme e em Esferocitose Hereditária. 2018. Tese (Doutorado). Faculdade de Medicina de Ribeirão Preto, Universidade de São Paulo.

INTRODUÇÃO: As Anemias Hemolíticas compreendem um grupo de doenças em que há redução acentuada na sobrevivência dos glóbulos vermelhos circulantes e a medula óssea não é capaz de compensação, mesmo aumentando sua produção, o que causa anemia desde os primeiros anos da vida da pessoa. Dentre as doenças deste grupo, a Anemia Falciforme (SCA) e a Esferocitose Hereditária (HS) destacamse por se tratarem de enfermidades com defeitos genéticos intrínsecos das células vermelhas (RBCs) que geram complicações multissistêmicas agudas e crônicas em seus portadores. Por vias patofisiológicas distintas, reticulócitos e respectivas hemácias defeituosas de tais doenças, falciformes e esferócitos, são continuamente aprisionados e fagocitados no baço, importante órgão de destruição de células velhas e/ou defeituosas via hemólise extravascular, o que leva progressivamente à disfunção e eventual perda da função esplênica. OBJETIVO: Avaliar o papel do baço em relação à habilidade e ao fenótipo adesivos de reticulócitos (ret) e eritrócitos (erit) em pacientes com SCA e HS, com e sem função esplênica preservada. METODOLOGIA: Amostras de sangue de 37 pacientes (22 SCA and $15 \mathrm{HS}$ ) com função esplênica e 19 pacientes (13 SCA e $6 \mathrm{HS}$ ) sem ela foram avaliadas. Ainda, sangue de 22 crianças com SCA foi coletado em estudo longitudinal dos 6 e 29 meses de vida. Todas as amostras de sangue foram analisadas quanto à função esplênica (Contagem de células PIT e de corpúsculos de Howell-Jolly - HJB), quanto ao perfil imunofenotípico celular (em \% e em média de intensidade de fluorescência - MFI) e quanto à habilidade de adesão das células vermelhas à laminina e à linhagem celular endotelial HMEC-1. RESULTADOS: A análise da transição da perda de função esplênica demonstrou que a mesma se intensificou a partir dos 3 anos de idade (PIT: $r=0,8$; $p<0,0001$; HJB: $r=0,7 ; p<0.0001)$. Quanto à imunofenotipagem celular, a contagem PIT se correlacionou positivamente, principalmente com os marcadores CD147 (\%ret: $r=0,6 ; p<0,0001$; MFIret: $r=0,6 ; p<0,0001$; \%erit: $r=0,7 ; p<0,0001$; MFlerit: $r=0,6 ; p<0,0001$ ), LuBCAM (\%ret: $r=0,5 ; p=0,004$; MFIret: $r=0,6 ; p<0,0001$; \%erit: $r=0,6 ; p<0,0003$; MFlerit: $r=0,4 ; p<0,004)$ and CD58 (\%ret: $r=0,4 ; p=0,006$; MFIret: $r=0,5 ; p<0,0013$; \%erit: $r=0,4 ; p<0,009$; MFlerit: $r=0,6 ; p<0,0001)$. Na comparação imunofenotípica entre ausência ou presença do baço, a perda de sua função exerceu influência no aumento da expressão de adesão de RBCs em SCA, principalmente CD147 (\%ret: $p=0,002$; MFIret: $p=0,003$; \%erit: $p<0,0001$; MFlerit: $p=0,005$ ), LuBCAM (\%ret: $p=0,0001$; MFIret: $p<0,0001$; \%erit: $p<0,0001$; MFlerit: $p<0,0001$ ) e CD58 (\%ret: $p=0,007$; MFIret: $p=0,006$; \%erit: $p=0,003$; MFlerit: $p=0,0004$ ), embora a adesão celular tenha diminuído em pacientes $\mathrm{HS}$ esplenectomizados. Na comparação entre as doenças, pacientes HS com o baço apresentaram maior freqüência de adesão celular em relação aos SCA, notavelmente em relação ao LuBCAM (\%ret: $p=0,0008$; MFIret: $p=0,03$; \%erit: $p<0,0001$; MFlerit: $p=0,0002$ ), CD58 (\%ret: $p=0,0009$; \%erit: $p=0,003$ ) e CD44 (\%ret: $p=0,009$; \%erit: $p<0,003$ ). No entanto, as amostras SCA sem função esplênica tiveram maior expressão de adesão celular para CD147 (\%ret: $p=0,006$; MFIret: $p=0,02$; \%erit: $p=0,02$ ), LuBCAM (\%ret: $p=0,004$; MFIret: $p<0,0001)$, CD36 (\%ret: $p=0,0002$; MFIret: $p=0,01)$, CD242 (\%ret: $p=0,0008$; \%erit: $p=0,05)$ e CD49d (\%ret: $p=0,04)$. Em relação ao Ensaio de Adesão in vitro, na ausência de baço, os RBCs SCA apresentaram maior adesividade à 
laminina do que os RBCs SCA com função esplênica preservada em todas as taxas de fluxo de tensão de cisalhamento empregadas $\left(0,5\right.$ dyne $/ \mathrm{cm}^{2}: p=0,01 ; 1 \mathbf{d y n e} / \mathbf{c m}^{2}$ : $p=0,02 ; 2$ dynes $/ \mathrm{cm}^{2}: p=0,03 ; 3$ dynes $/ \mathrm{cm}^{2}: p=0,03 ; 5$ dynes $/ \mathbf{c m}^{2}: p=0,04$ e 7 dynes $\left./ \mathrm{cm}^{2}: \quad p=0,03\right)$. Especialmente, reticulócitos de pacientes sem baço apresentaram maior adesividade à HMEC-1 em baixas tensões de cisalhamento (1

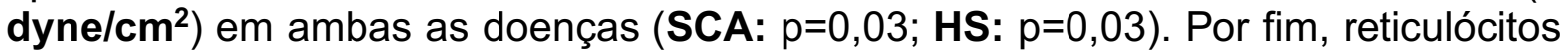
apresentaram maior habilidade adesiva à células endoteliais em indivíduos SCA do que em pacientes HS, com $\left(0,5\right.$ dyne $/ \mathbf{c m}^{2}: p=0,04 ; 1$ dyne $\left./ \mathbf{c m}^{2}: p=0,03\right)$ ou sem baço (0,5 dyne $/ \mathrm{cm}^{2}: p=0,02 ; 2$ dynes $/ \mathrm{cm}^{2}: p=0,01 ; 3$ dynes $/ \mathrm{cm}^{2}: p=0,03 ; 5$ dynes $/ \mathrm{cm}^{2}$ : $p=0,02$ e 7 dynes/cm²: $p=0,03$ ). CONCLUSÃO: Nossos resultados indicam que embora pertençam ao grupo de Anemias Hemolíticas, as patofisiologias e evoluções clínicas distintas de SCA e de HS levam a padrões imunofenotípicos diferentes de expressão da adesão celular. Na SCA, a ausência de função esplênica teria direta relação com o aumento do fenótipo pró-adesivo e com a adesividade de RBCs SCA, o que traz sérias consequências clínicas aos pacientes, enquanto na HS sem baço, de maneira geral, os eventos de adesão celular são minimizados, embora ainda apresentem reticulócitos e eritrócitos adesivos circulantes após a esplenectomia.

Palavras-chave: Anemia Falciforme, Função Esplênica, Reticulócitos, Adesão Celular, Baço, Esferocitose Hereditária. 


\section{ABSTRACT}

FERREIRA, P. C. G. Splenic function and cellular adhesion events in Sickle Cell Anemia and in Hereditary Spherocytosis. 2018. Thesis (Doctorate). Ribeirão Preto Medical School, Univerity of São Paulo.

INTRODUCTION: Hemolytic Anemias comprise a group of diseases in which there is marked reduction in the survival of circulating erythrocytes and the bone marrow is not capable of compensation, even by increasing its production, which causes anemia from the first years of the person's life on. Among the diseases of this group, Sickle Cell Anemia (SCA) and Hereditary Spherocytosis (HS) stand out for being diseases with intrinsic genetic defects of red blood cells (RBCs) that generate acute and chronic multisystemic complications in their patients. By distinct pathophysiological pathways, reticulocytes and these disease's respective defective erythrocytes, sickle and spheroid ones, are continuously trapped and phagocytosed in the spleen, important organ of destruction of old and/or defective cells via extravascular hemolysis, which progressively leads to dysfunction and eventual loss of splenic function. OBJECTIVE: To evaluate the role of the spleen in relation to the reticulocyte (ret) and erythrocyte (eryt) adhesive ability and adhesion phenotype in patients with SCA and HS, with and without preserved splenic function. METHODOLOGY: Blood samples from 37 patients (22 SCA and $15 \mathrm{HS}$ ) with splenic function and 19 patients (13 SCA and $6 \mathrm{HS}$ ) without it were evaluated. Still, blood from 22 children with SCA was collected in a longitudinal study from 6 to 29 months of age. All blood samples were analyzed for splenic function [pitted cells (PIT) and Howell-Jolly bodies (HJB) counting], for the cellular immunophenotypic profile (in \% and in mean fluorescence intensity - MFI) and for the adhesive ability of RBCs to laminin and to endothelial cell line HMEC-1. RESULTS: Analysis of the splenic function loss transition showed that it intensified from 3 years of age on (PIT: $r=0.8, p<0.0001$; HJB: $r=0.7, p<0.0001$ ). Regarding the cellular immunophenotyping, PIT count correlated positively, mainly with CD147 markers (\%ret: $r=0.6, p<0.0001$; MFIret: $r=0.6, p<0.0001$; \%eryt: $r=0.7, p<0.0001$; MFleryt: $r=0.6, p<0.0001$ ), LuBCAM (\%ret: $r=0.5, p=0.004$; MFIret: $r=0.6, p<0.0001$; \%eryt: $r=0.6, p<0.0003$; MFleryt: $r=0.4, p<0.004$ ) and CD58 (\%ret: $r=0.4, p=0.006$; MFIret: $r=0.5, \quad p<0.0013$; \%eryt: $r=0.4, p<0.009$; MFleryt: $r=0.6, p<0.0001)$. In the immunophenotypic comparison between spleen absence or presence, the loss of its function exerted influence on the increase of RBCs adhesion expression in SCA, mainly on CD147 (\%ret: $p=0.002$; MFIret: $p=0.003$; \%eryt: $p<0.0001$; MFleryt: $p=0.005$ ), LuBCAM (\%ret: $p=0.0001$; MFIret: $p<0.0001$; \%eryt: $p<0.0001$; MFleryt: $p<0.0001$ ) e CD58 (\%ret: $p=0.007$; MFIret: $p=0.006$; \%eryt: $p=0.003$; MFleryt: $p=0.0004)$, although cell adhesion has been decreased in splenectomized HS patients. In the comparison between diseases, HS patients with spleen showed higher cell adhesion frequency compared to SCA, notably in relation to LuBCAM (\%ret: $p=0.0008$; MFIret: $p=0.03$; \%eryt: $p<0.0001$; MFleryt: $p=0.0002$ ), CD58 (\%ret: $p=0.0009$; \%eryt: $p=0.003$ ) and CD44 (\%ret: $p=0.009$; \%eryt: $p<0.003$ ). However, SCA samples without splenic function had higher cell adhesion expression for CD147 (\%ret: $p=0.006$; MFIret: $p=0.02$; \%eryt: $p=0.02$ ), LuBCAM (\%ret: $p=0.004$; MFIret: $p<0.0001)$, CD36 (\%ret: $p=0.0002$; MFIret: $p=0.01$ ), CD242 (\%ret: $p=0.0008$; \%eryt: $p=0.05)$ and CD49d (\%ret: $p=0.04)$. Concerning the in vitro Adhesion Assay, in the spleen absence, SCA RBCs showed greater adhesiveness to laminin than SCA RBCs with preserved splenic function did at all shear stress flow rates applied $(0.5$ dyne $/ \mathrm{cm}^{2}: p=0.01,1$ dyne $/ \mathrm{cm}^{2}: p=0.02,2$ dynes $/ \mathrm{cm}^{2}: p=0.03,3$ dynes $/ \mathrm{cm}^{2}: p=0.03$, 
5 dynes $/ \mathbf{c m}^{2}: p=0.04$ and 7 dynes $/ \mathbf{c m}^{2}: p=0.03$ ). Especially, reticulocytes from patients without spleen showed higher adhesiveness to HMEC-1 at low shear stresses (1 dyne $/ \mathbf{c m}^{2}$ ) in both diseases (SCA: $p=0.03$; HS: $p=0.03$ ). Finally, reticulocytes showed greater adhesion ability to endothelial cells in SCA subjects than in HS patients, with $\left(\mathbf{0 . 5}\right.$ dyne $/ \mathbf{c m}^{2}: p=0.04$ and $\mathbf{1}$ dyne/cm $\left.\mathbf{c m}^{2}: p=0.03\right)$ or without spleen $(\mathbf{0 . 5}$ dyne $/ \mathrm{cm}^{2}: \mathrm{p}=0.02,2$ dynes $/ \mathrm{cm}^{2}: \mathrm{p}=0.01,3$ dynes $/ \mathrm{cm}^{2}: \mathrm{p}=0.03,5$ dynes $/ \mathrm{cm}^{2}$ : $p=0.02$ and 7 dynes $/ \mathrm{cm}^{2}: p=0.03$ ). CONCLUSION: Our results indicate that although both diseases belong to the Hemolytic Anemias group, SCA and HS distinct pathophysiologies and clinical evolution lead to different immunophenotypic patterns of cell adhesion expression. In SCA, the absence of splenic function may have a direct relation with the increase of SCA RBCs pro-adhesive phenotype and adhesiveness, which brings serious clinical consequences to the patients, whereas in HS without spleen, in general, cellular adhesion events are minimized, although they still present adhesive circulating reticulocytes and erythrocytes after splenectomy.

Keywords: Sickle Cell Anemia, Splenic Function, Reticulocytes, Cellular Adhesion, Spleen, Hereditary Spherocytosis. 


\section{LIST OF ABBREVIATIONS}

\begin{tabular}{ll} 
AB & Antibody \\
BSA & Bovine serum albumin \\
BT & Total bilirubin \\
CD & Cluster of differentiation \\
CONEP & National Commission for Ethics on Research \\
DIC & Differential Interference Contrast Microscopy \\
EDTA & Etilenodiaminotetracetic acid \\
FBS & Fetal bovine serum \\
Hb & Hemoglobin \\
HbF & Fetal hemoglobin \\
HBSS & Hank's balanced salt solution \\
HC & Hydroxycarbamide \\
HCFMRP & Clinical Hospital of the Ribeirão Preto Medical School \\
Hct & Hematocrit \\
HEPA & High efficiency particulate air \\
HEPES & 4-(2-hydroxyethyl)-1-piperazineethanesulfonic acid \\
HJB & Howell-Jolly bodies \\
HMEC-1 & Transfected Human Dermal Microvascular Endothelial Cells - 1 \\
HS & Hereditary Spherocytosis \\
HSA & Human serum albumin \\
IgG & Immunoglobulin G \\
LDH & Lactate dehydrogenase \\
LuBCAM & Basal cell adhesion molecule (Lutheran blood group), also \\
MCDB131 & Mown as CD239 \\
MCHC & Mean corpuscular hemoglobin concentration \\
MCV & Medium corpuscular volume \\
MFI & Mean fluorescence intensity \\
PALS & Periarteriolar lymphoid sheaths \\
PBS & Phosphate buffered saline \\
PE & Phycoerythrin \\
PIT & Pitted cells \\
RBC & Red blood cells \\
rpm & Revolutions per minute \\
\hline ing
\end{tabular}


RPMI Roswell Park Memorian Institute medium

RT Room temperature

SCA Sickle Cell Anemia

TNF- $\alpha \quad$ Tumor Necrosis Factor- $\alpha$ human

w with

WBC White blood cell

w/o without 


\section{LIST OF FIGURES}

Figure 1. Cell adhesion assay curve.

Figure 2. Quantification of splenic dysfunction in SCA patients between 6 and 29 months of age.

Figure 3. Quantification of splenic dysfunction in SCA patients with and without preserved splenic function.

Figure 4. Quantification of splenic dysfunction in HS patients with and without

spleen.

Figure 5. Morphology of pitted cells and HJB cells in SCA and HS samples.

Figure 6. Relation between splenic function and $\mathrm{HbF}$ serum levels in SCA patients with and without spleen.

Figure 7. Correlation between CD147 and splenic function loss. 38

Figure 8. Correlation between LuBCAM and splenic function loss. 39

Figure 9. Correlation between CD58 and splenic function loss. 40

Figure 10. Correlation between CD242 and splenic function loss. 41

Figure 11. Correlation between CD99 and splenic function loss. 42

Figure 12. Correlation between CD108 and splenic function loss 43

Figure 13. Correlation between CD44 and splenic function loss. 44

Figure 14. Correlation between CD47 and splenic function loss. 45

Figure 15. Correlation between CD36 and splenic function loss. 46

Figure 16. Correlation between CD49d and splenic function loss. 47

Figure 17. Correlation between CD151 and splenic function loss 48

Figure 18. Distribution of circulating adhesive cells in the spleen 51 absence/presence in SCA and HS patients.

Figure 19. Distribution of adhesive cells according to the type of disease 54 (SCA and HS). 
Figure 20. RBCs adhesive ability under flow conditions with increasing 58 shear stress in the spleen absence/presence in SCA.

Figure 21. RBCs adhesive ability under flow conditions with increasing shear stress in the spleen absence/presence in HS.

Figure 22. RBCs adhesive ability under flow conditions with increasing shear stress, according to the type of disease (SCA and HS with spleen)...

Figure 23. RBCs adhesive ability under flow conditions with increasing shear stress, according to the type of disease (SCA and HS without 62 spleen) 


\section{SUMMARY}

1. INTRODUCTION............................................................ 2

1.1. Hereditary Hemolytic Anemia..................................... 2

1.2. Sickle Cell Anemia..................................................... 4

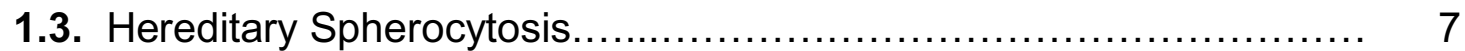

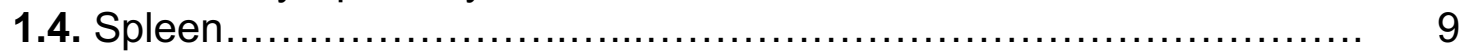

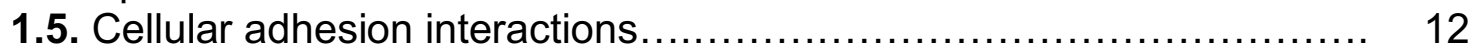

2. HYPOTHESIS ............................................................ 15

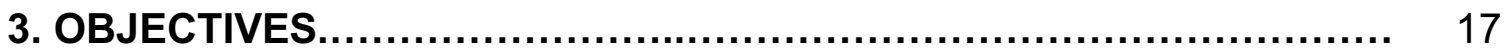

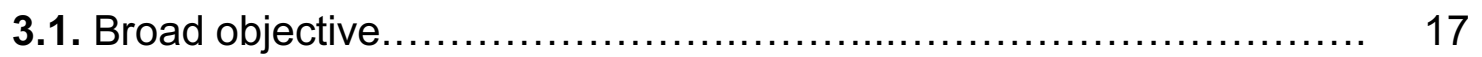

3.2. Specific objectives............................................... 17

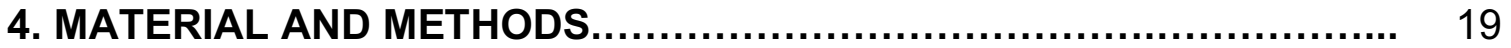

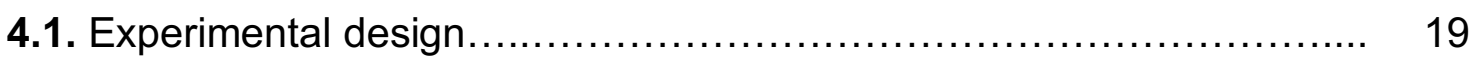

4.1.1. Follow-up of the splenic function loss transition...................... 19

4.1.2. Analysis of splenic function loss in SCA and in HS patients........... 19

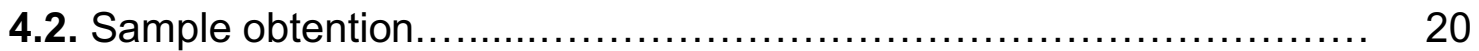

4.3. Red blood cell freezing and thawing............................... 20

4.4. Pitted cells counting.................................................. 22

4.5. Howell-Jolly bodies counting .......................................... 22

4.6. Cellular immunophenotyping......................................... 23

4.7. Cellular adhesion assay.............................................. 24

4.7.1. Expansion of the HMEC-1 lineage ................................. 24

4.7.2. Treatment with laminin ............................................... 25

4.7.3. Adhesion assay preparation....................................... 25

4.7.4. Blood sample preparation........................................ 26

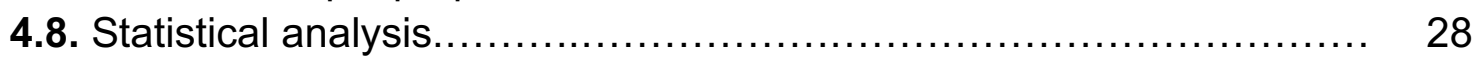

5. RESULTS AND DISCUSSION.............................................. 30

5.1. Splenic function quantification........................................ 30

5.1.1. Splenic function quantification in SCA children between 6 to 2930

5.1.2. Splenic function quantification in SCA subjects from 3 years of life on and in HS subjects.

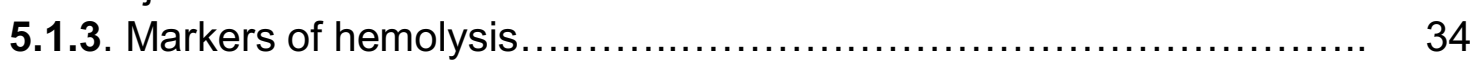

5.2. Cellular immunophenotyping .................................... 36

5.2.1. Adhesion markers versus PIT counting comparison................. 36

5.2.2. Spleen absence/presence comparison............................ 49

5.2.3. Disease type comparison..................................... 52

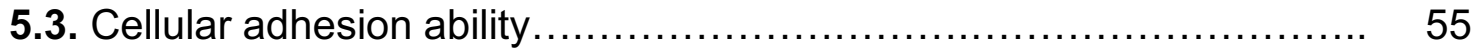

5.3.1. Spleen absence/presence comparison.......................... 55

5.3.2. Disease type comparison....................................... 60 
6. CONCLUSION........................................................ 64

7. BIBLIOGRAPHIC REFERENCES...................................... 67

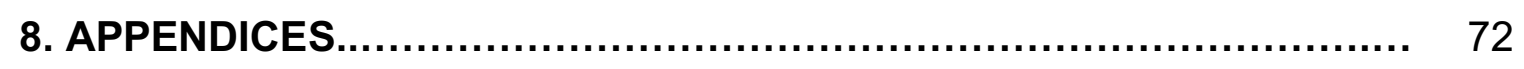

8.1. Appendix I - Informed consent form for the collection and use of 72
biological material...

8.2. Appendix II - Informed consent form for the storage of biological 72

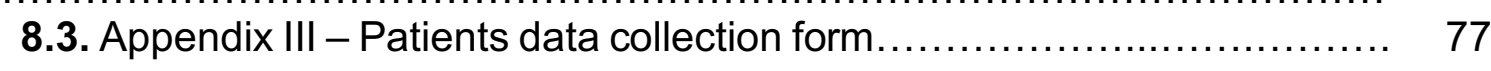


INTRODUCTION 


\section{INTRODUCTION}

\subsection{Hemolytic Hemolitic Anemias}

Hemolytic Hemolytic Anemias comprise a group of diseases in which there is a marked reduction in the survival of circulating red blood cells and the bone marrow is not capable of compensation even by increasing its production. There are several diseases included in the Hemolytic Anemias group. They may occur due to intrinsic or extrinsic defects of the red blood cells. The present study deals with the first classification of defects, the intrinsic ones, which in turn can be subdivided into three categories: 1) hemoglobin abnormalities; 2) abnormalities of the RBC membrane; 3) abnormalities of erythrocyte enzymes. (Dhaliwal, et al., 2004; Zago, et al., 2013). Of the two diseases addressed in this work, the first one, Sickle Cell Anemia (SCA) is caused by a hemoglobin abnormality and the second one, Hereditary Spherocytosis (HS), is due to an abnormality of the RBC membrane.

Hemoglobin $(\mathrm{Hb})$ is a protein abundant in red blood cells, composed of two types of globin chain in vertebrates. In humans, it can be encoded from seven paralogous genes $(\alpha, \beta, \gamma, \delta, \varepsilon, \zeta$ and $\theta$ ) that are transcribed at different stages of development. The $\varepsilon$-globin gene is expressed in the early embryo, $\mathrm{Y}$ in the late embryo and in the fetus, and $\delta$ and $\beta$ are expressed mainly in adults. Each $\mathrm{Hb}$ molecule is a complex of two chains of two types (for example, two a chains and two $\beta$ ones $-\alpha_{2} \beta_{2}$ ), which form four binding sites (heme groups) to the iron atom. The oxygenation process, in its turn, takes place with the iron interaction with the oxygen molecule. That process allows a reversible cooperative allosteric modification in the $\mathrm{Hb}$ as it binds to oxygen and releases it (Alberts, et al., 2010).

There are two mechanisms of hemolysis: the intravascular and the 
extravascular. In the first mechanism, there is the destruction of red blood cells in the circulation with the release of cell contents into the plasma. Mechanical trauma from a damaged endothelium, complement fixation and activation on the cell surface, and infectious agents may cause direct membrane degradation and cell destruction. In its turn, extravascular hemolysis is the removal and destruction of red blood cells with membrane alterations by the macrophages of the spleen and liver (Dhaliwal, et al., 2004).

In the natural hemolysis process, when RBCs rupture, the released hemoglobin is phagocytosed by macrophages. Globin chains of hemoglobin are then broken down to individual amino acids that are metabolized or used to build new proteins. Iron is released from the heme fraction of the hemoglobin and the remaining structure is converted into biliverdin, which is then converted into bilirubin by the enzyme biliverdin reductase. Iron is transported by transferrin in the blood to some tissues, such as liver and spleen, for storage or to the bone marrow for making new hemoglobin, while free bilirubin is transported by albumin in the blood to the liver. Hepatocytes conjugated bilirubin which is excreted as part of the bile in the small intestine and intestinal bacterias convert bilirubin into bilirubin derivatives which contribute to the color of feces. Some of the bilirubin derivatives are absorbed into the blood and are excreted from the kidneys. Elevated levels of bilirubin in the blood together with other laboratory tests with further markers of hemolysis may be indicative of intravascular hemolysis (Embury, et al., 1994; Zago, et al., 2013).

In this context, intravascular hemolysis may be related to important implications of the Hemolytic Anemias pathophysiology. For instance, Nouraie et al (2013) derived a hemolytic component from well-known markers of hemolysis 
and confirmed based on this component that associations between the patients' hemolytic rate and important clinical outcomes in SCA, such as systemic hypertension, increases in Doppler-estimated pulmonary systolic pressures, endothelial dysfunction and mortality, are determined in part by the process of intravascular hemolysis.

\subsection{Sickle Cell Anemia}

Of the intrinsic defects of the red blood cells that can lead to Hemolytic Anemias, the first aforementioned, the hemoglobin abnormality, encompasses a very important group of disorders, the Sickle Cell Diseases (SCD). Such group is divided into ethnic subgroups of geographically distinct regions according to the haplotype of $\beta$-globin $S$ that they carry, which include Senegal (SEN), Benin (BEN), Bantu or Central African Republic (CAR), Cameroon (CAM) and ArabicIndian (ARAB) (Logetto, 2013). The highest prevalence of SCD takes place in the sub-Saharan Africa. Data from the World Health Organization in 2008 have estimated that over 330,000 children are born annually affected with some hemoglobin disorder, and of this number, 83\% account for Sickle Cell Disorders (Modell and Darlison, 2008)

SCD distribution of the disease worldwide is due to two main factors: the selection of carriers for their advantage over endemic areas of malaria and to the population migration. SCA genes have arisen in areas where the protozoan parasite Plasmodium falciparum that causes malaria is endemic and it is believed that the high levels of prevalence of such genes in these regions confer resistance of the sickle $\mathrm{RBC}$ to the protozoan. Therefore, this fact introduced selective pressure in the human genome and erythrocytes became the main 
target for evolutionary adaptation. In fact, the greater resistance of the sickle cell trait carriers that is, asymptomatic carriers, to malaria is considerable and infected asymptomatic heterozygous children have lower parasite densities than healthy children and are $50 \%-90 \%$ less likely to progress to a severe form of malaria or to die from the disease (Bunn, 2013). According to the historical origin of the Afrodescendant population in Brazil as a result of the slave trade, the most common haplotype of $\beta$-globin $S$ is CAR, followed by BEN, mainly in the northeastern and southeastern regions of the country (Loggetto, 2013).

Individuals with SCD necessarily inherit a maternal and a paternal mutation. Inherited mutations may be homozygous (SS), the only genotype that can be termed as "Sickle Cell Anemia", or compound heterozygous, that is, the disease is caused by the inheritance of hemoglobin $\mathrm{S}(\mathrm{HbS})$ in combination with another defect (structural or synthetic) in $\mathrm{Hb}$ [SC, SD, SE, S beta-thalassemia (SBetaTAL), S alpha-thalassemia or S rare mutant]. It is estimated that $4 \%$ of the Brazilian population carries the sickle cell trait (simple heterozygosis) and that 25,000 to 50,000 people have the disease in the homozygous state (SS - SCA) or in compound or double heterozygous (SC, SE, SD, SBetaTAL - SCD) (Ministério da Saúde - Brasil, 2016).

SCA is an autosomal recessive hereditary disease that gives rise to hemoglobin $\mathrm{S}(\mathrm{HbS})$, an abnormal $\mathrm{Hb}$. This defect happens due to a point mutation in codon 6 of the $\beta$-globin gene that is present on the short arm of chromosome 11. The alteration causes the substitution of the adenine nucleotide for thymine (from GAG to GTG) which leads to the generation of the mutant amino acid valine instead of the normal amino acid glutamic acid (Maier-Redelsperger, et al., 1998; Lodish, et al., 2002; Voskaridou, et al., 2012). 
This mutation leads to serious consequences for the individual, such as RBCs sickling. In it, $\mathrm{HbS}$ polymerizes reversibly when it undergoes deoxygenation in low oxygen stress situations and forms fibrous intracellular crystalline aggregates that harden the erythrocyte membrane, increase viscosity and cause dehydration due to the escape of potassium and the influx of calcium into the cell. RBCs morphology of the red blood cells changes and acquires a sickle shape, which causes the cells to lose the ability to carry oxygen and to travel through small capillaries properly (Darghouth et al., 2011; Voskaridou, et al., 2012). Sickle RBCs specifically alter the adhesion molecules expression pattern on their surface and start adhering abnormally to the endothelium of smaller vessels. Microvascular vasoconstriction and immature erythrocyte destruction processes are established and lead the patient to severe Hemolytic Anemia state (Darghouth et al., 2011; Voskaridou, et al., 2012; Rees, et al., 2010). Although this sickling phenomenon may be reversible with reoxygenation, when systematically repeated, it may intensify the functional alterations and the cell becomes irreversibly sickled (Naoum and Naoum, 2004).

The symptoms that result from this genetic alteration are, therefore, serious and worthy of mention. Erythrocytes of affected individuals become rigid and their traffic through the capillaries becomes blocked, which causes severe pain and tissue injury (Lodish, et al., 2002). Vasocclusion events promote ischemia, hemolysis and tissue inflammation, which leads to acute pain, acute chest syndrome, hyposplenism, osteonecrosis and nephropathy in patients, among other complications. Reperfusion episodes may also lead to pulmonary hypertension, priapism, leg ulcers, and cerebrovascular disease (Embury, et al., 1994; Rees, et al., 2010). 
Thus, the rate of hemolysis and the degree of anemia have important pathophysiological and clinical consequences in sickle cell anemia. A decreased hemoglobin concentration leads to decreased delivery of oxygen to the tissues. Intravascular hemolysis leads to the release of hemoglobin and arginase-1 into the plasma, into the scavenging of plasma NO by cell-free hemoglobin, and into the depletion by arginase- 1 of plasma arginine, the obligate substrate for the NO synthases. These processes may contribute to reduced NO bioavailability and vascular dysfunction, which leads to the endothelium activation and a cicle of RBC sickling and to the vasoclusive events. (Chiang and Frenette, 2005; Nouraie et al., 2013).

\subsection{Hereditary Spherocytosis}

Hereditary spherocytosis is a type of Hemolytic Anemia, responsible for qualitative and/or quantitative alterations of the erythrocyte membrane proteins. Some typical morphological alterations are high osmotic fragility and increased density and spherical shape which leads to decreased survival of the erythrocytes due to marked degradation carried out by the spleen (An and Mohandas, 2008; Gallagher, 2013).

HS prevalence is high in northern European populations (approximately $50 / 1000,000)$, lower in latin white populations $(20$ to $30 / 100,000)$ and even smaller in black and yellow populations. Hereditary spherocytosis is a genetic autosomal dominant disorder. However, about $10 \%$ of those people affected do not present any type of family history related to the disease, in which case the pathology comes from some type of mutation (Granjo et al, 2003). 
The disease genetic alterations generate modifications in erythrocyte membrane proteins, such as spectrin, band-3 protein, protein 4.2 , but mainly on ankyrin. The membrane proteins, associated to the lipid bilayer are supposed to provide rigidity and integrity to the erythrocyte membrane. Nevertheless, due to the genetic alteration, erythrocytes lose vertical linkage between membrane skeleton and lipid bilayer and undergo microvesiculations formation, which decrease the surface area without altering the cell volume. Importantly, the severity of anaemia is directly related to extent of membrane surface area loss. With decrease in $\mathrm{pH}$, glucose concentrations, ATP and the increase in the number of circulating free radicals, events like loss of elasticity and difficulties in the passage through the endothelial cells and the spleen may become frequent and eventually lead to great splenic vascular congestion (An and Mohandas, 2008; Gallagher, 2013; Zago, et al., 2013).

Main HS clinical symptoms encompasses jaundice, likely to happen with hemolysis of any kind, splenomegaly and gallstones formation. To indentify HS, the most characteristic feature is increase of $\mathrm{MCHC}$ (mean corpuscular hemoglobin concentration) due to the dehydration caused by loss of $\mathrm{K}^{+}$ions and water (Gallagher, 2013; Zago, et al., 2013).

Regarding the HS treatment, splenectomy is generally recommended for patients from 5 years of age on who present splenomegaly, reticulocytosis, hypoplastic and aplastic crises, growth deficit or cardiomegaly. However, once considered routine, growing recognition of the longterm risks of splenectomy, including cardiovascular disease, thrombotic disorders, and pulmonary hypertension, as well as the emergence of penicillin-resistant pneumococci, a concern for infection in overwhelming postsplenectomy infection, have led to re- 
evaluation of the role of splenectomy. Vaccinations have been shown to play an important role in reducing the number of cases of sepsis mortality after splenectomy (An and Mohandas, 2008; Zago, et al., 2013).

\subsection{Spleen}

The spleen is an intraperitoneal organ located on the left side of the body, right below the ribs and it lies in the left upper quadrant, under the diaphragm. This organ is covered by a capsule and consists of two major types of tissue: the red pulp and the white pulp. The red pulp is where the red blood cells (RBCs) undergo a refined quality control while the white pulp is part of the immune system, in which by the way, the spleen has a very important role by scanning the blood for evidence of bacterial infection (Embury, et al., 1994)

There are two circulatory routes through the splenic pulp: open and closed circulation. In a nutshell, a closed "fast flow" circulation drains blood directly into the venous sinusoids, flowing together to become trabecular veins. In an open "slow flow" circulation, blood flows into a reticular fibrous framework of the red pulp and/or via the marginal zone of the lymphatic tissue before reaching the sinusoids (Vancauwenberghe, et al., 2015).

So, the blood system in the spleen holds a unique open system consisted of trabeculae coming within the tissue. Blood comes in through the trabecular artery and into the central artery. In its surrounding area, there are a lot of lymphocytes forming the periarteriolar lymphoid sheaths (PALS), that are a massive lymphoid tissue consisted mainly of $T$ cells and macrophages, which screens the blood for the presence of bacteria and viruses and initiates antibody responses against those as well as producing antibodies. Surrounding the PALS, 
there is another lymphoid tissue called the marginal zone, which is made of predominantly macrophages. Within this tissue, there are other lymphatic tissues called follicles, which are essentially surrounded by the marginal zone and contain immune B cells. Together, the PALS, the marginal zone and the follicles form what so-called white pulp of the spleen (Vancauwenberghe, et al., 2015; Steiniger, 2015; Embury, et al., 1994).

On the blood way into the spleen, splenic arteries go into capillaries which eventually break down, lose their wall structure and the RBCs end up in formations called venus sinuses. In the natural splenic physiology, RBCs very slowly migrate in these very large sinuses in the presence of many macrophages that, in their turn, scan the red cells for any evidence of dysfunction, in order to remove old damaged red cells from the blood. Between the end arteries and the venus sinuses, there is an area of tissue called the cords, which contains plenty of macrophages. Together, the cords and the venus sinuses make up the red pulp above-mentioned. The white pulp represents around $25 \%$ of the splenic tissue, which makes the other $75 \%$ consisted of the red pulp, but the ratio of white to red pulp increases with age due to accumulated antigenic exposure and stimulation (Brousse, et al., 2014; Steiniger, 2015).

Thus, the main role of the splenic red pulp is to destroy or filter abnormal, unhealthy or older RBCs. To do so, the slits presented between the endothelial cells of the venus sinuses are important. When these cells move into the venus sinuses, they are drained into the collecting veins before being drained into the splenic vein. However, old and defective RBCs are unable to pass through the slits effectively and thus are phagocytized by the surrounding macrophages. 
Then, the cleaned or healthy RBCs are released back into the splenic vein and into the blood system (Embury, et al., 1994; Brousse, et al., 2014).

If the spleen is removed from a person, one will produce lower amounts of antibodies and will be at an increased risk of infection. Besides that, the blood of an splenectomized person presents an increased number of abnormal RBCs in the circulation, such as those containing Howell-Jolly bodies (HJB), which are remnants of the nucleus from the erythropoiesis maturation process (Corazza, et al., 1990; Brousse, et al., 2014). HJB presence is also related to hyposplenism, even when the spleen remains with a normal size or enlarged, the so-called functional hyposplenism (Covas and Zago, 1987; Sears and Udden, 2012). Still, another important marker of splenic dysfunction observed in splenectomized individuals is the presence of vacuoles on RBCs surface when observed under Interference Contrast Microscopy, which has also become another diagnostic factor for hyposplenism (Natham and Gunn, 1966; Brousse, et al., 2014).

On the other hand, one of the criteria used for the diagnosis of hypersplenism is the presence of splenomegaly. Enlargement of the splenic volume occurs in proportion to the increase in the RBC volume stored in the expanded extra sinus spaces. In this situation, normal RBCs penetrating the splenic red pulp face adverse conditions represented by high hematocrit (Hct) and decrease in the energetic substrates levels and in ph levels. Together, these factors lead to the drop of ATP levels with consequent instability and loss of membrane components, decrease in deformability and consequent erythrocytes retention and lysis (Covas, 1985).

Briefly, splenic injury is generally silent and progressive. It can be clinically overt with acute splenic sequestration of red cells, an unpredictable and life- 
threatening complication in infants. Splenomegaly, with or without hypersplenism, can also occur and can coexist with loss of function. Hyposplenism, in its turn, increases the susceptibility of SCA children to infection with encapsulated bacteria, which is notably reduced by penicillin prophylaxis and immunization (Brousse, et al., 2014).

\subsection{Cellular adhesion interactions}

The bone marrow is responsible for the process of erythropoiesis, which consists of several stages of differentiation, from erythroid colony forming units to mature red cells. Such process may also occur extramedullary in other organs, such as the spleen in specific cases (Chasis, 2006; Zago, et al., 2013).

Macrophages are known for the major role in terminal erythropoiesis in a specialized microenvironment called the erythroblastoside island. In this structure, erythroblasts receive the necessary conditions for their maturation and their expelled nucleus undergoes phagocytosis by the central macrophage (Chasis, 2006; De Back, et al., 2014). The close relationship between macrophage and erythroblasts is evidenced in the expression of various surface markers such as VCAM-1 and $\alpha \mathrm{V}$ integrin in macrophages and $\alpha 4 \beta 1$ and ICAM4 integrin in erythroblasts (Chasis, 2006; De Back, et al., 2014).

With the release of sickle erythrocytes, in SCA, and of early reticulocytes in Hemolytic Anemias in general into the circulation, the spleen plays a crucial role in the clearance of these abnormally more adhesive cells because it already naturally has a destructive role in the recycling process of old erythrocytes, when extravascular hemolysis takes place (Manwani and Bieker, 2008). Therefore, it is relevant to analyze the adhesion molecules expression pattern of immature or 
defective cells released into the circulation in the absence and presence of this organ in Hemolytic Anemias.

Nowadays, there are some methods available that allow us to assess the splenic function and some adhesion molecules that may be important in spleen function absence. In addition to conducting the immunophenotypic study of the cells of interest, one of the possible approaches to investigate the adhesive abilities of the pathophysiological characteristics of Hemolytic Anemias in vitro is to evaluate patients' blood regarding their rheological properties. Knowing the RBCs adhesion behavior against some substrates via molecular interactions is of great importance in the study of Hemolytic Anemias, particularly at low shear stress flow rates that mimic the natural microcapillaries flow, once it can provide information on cell-cell and on cell-extracellular matrix interactions via, for instance, an adhesion assay (El Nemer, et al., 2008). 
HYPOTHESIS 


\section{HYPOTHESIS}

The chronic hemolysis observed in SCA causes early release into the circulation of young reticulocytes that, together with the disease characteristic circulating sickle erythocytes, express greater number of adhesion molecules, which stimulates the vasocclusive phenomenon. In this context, the investigation of the splenic role on the cellular adhesion profile and on the cellular adhesiveness in SCA becomes as necessary as in other Hemolytic Anemias, such as HS for instance. However, by presenting chronic hemolysis caused by a different pathophysiological mechanism, HS offers, in turn, a counterpoint to the process of red blood cell sickling and of VO crisis in SCA and their consequences for the splenic function, that is noteworthy.

Besides the role in the removal of old erythrocytes, the spleen has an important protective function, contributing to the decrease of peripheral blood cells that abnormally express adhesion molecules on their surface, such as sickle erythrocytes and those with membrane defects. Therefore, the loss of splenic function would initially have a direct relationship with the increase of pro-adhesive phenotype and adhesiveness of reticulocytes and red blood cells in the peripheral circulation of patients with SCA and HS. 
OBJECTIVES 


\section{OBJECTIVES}

\subsection{Broad objective}

To evaluate the role of the spleen in relation to the adhesive phenotype and ability of reticulocytes and erythrocytes in patients with Hemolytic Anemias.

\subsection{Specific objectives}

- To assess the splenic function loss transition in patients with Sickle Cell Anemia;

- To assess the correlation of splenic function loss (PIT counting) with the increase of circulating adhesive reticulocytes and erythrocytes in SCA and HS;

- To evaluate the influence of the spleen presence or absence on the adhesion expression of circulating reticulocytes and erythrocytes of patients with SCA and HS;

- To assess the influence of the two diseases addressed in this study, SCA and $\mathrm{HS}$, regarding the adhesion expression on their circulating reticulocytes and erythrocytes at the same condition, either with or without spleen.

- To compare the spleen role on the adhesive potential of circulating reticulocytes and erythrocytes of SCA and HS patients in an in vitro Cell Adhesion Assay.

- To compare the adhesive potential of circulating reticulocytes and erythrocytes between both diseases at the same condition, either with or without spleen in an in vitro Cell Adhesion Assay. 
MATERIAL AND METHODS 


\section{MATERIAL AND METHODS}

\subsection{Experimental design}

The groups were divided according to the type of disease and, within the group of patients with Sickle Cell Anemia, according to the transition range of the splenic dysfunction evolution considered in the literature, which points to the period between 1 and 2 years of age (Pearson, et al., 1985; Rogers et al., 2011). Thus, for the purpose of categorization, patients with up to 2 years and 5 months of age were included in the group called SCA with preserved splenic function, and in turn, the SCA group without preserved splenic function was constituted of individuals 3 years old or older participating in the research.

\subsubsection{Follow-up of the splenic function loss transition}

- $\quad$ SCA group with preserved splenic function - in this first group approach, a longitudinal study has been conducted in order to evaluate the spleen parameters of individuals affected by SCA with up to 2 years and 5 months of age, specifically in the following time Windows of 4 months each: from 6 to 9 , from 10 to 13 , from 14 to 17 , from 18 to 21 and from 22 to 29 months of life.

\subsubsection{Analysis of splenic function loss in SCA and in HS patients}

Groups of patients whose blood samples were collected for this analysis are as it follows:

- $\quad$ SCA group with preserved splenic function - children mentioned above were also considered in this second approach of the study, as the group that has not completely lost splenic function yet and that, therefore, is in this transition. 
- $\quad$ SCA group without preserved splenic function - SCA patients from 3 years old, as the group without splenic function or with almost complete loss of it.

- HS group with spleen - HS patients who still have the spleen.

- HS group without spleen -HS splenectomized patients.

Patients who presented any disease in their health history that might affect their immunity or splenic function, blood transfusion within the previous 3 months of collection or a severe sepsis episode were excluded. This selection has been made based on the analysis of the exams held in the patients' medical records, so that no additional examination has been requested for this project's development.

\subsection{Sample obtention}

This is an observational study whose permission for sample obtention was previously approved by the Research Ethics Committee of HC-FMRP and by CONEP (CAAE: 46629915.0.000.5440). The Informed Consent Form for the collection and use of biological material and the Informed Consent Form for the storage of biological material given to the participants are shown respectively in Appendices 8.1 and 8.2.

\subsection{Red blood cell freezing and thawing}

From each fresh blood sample collected in EDTA tubes, $2 \mathrm{~mL}$ were separated to be frozen and stored. Blood samples were centrifuged at $2500 \mathrm{rpm}$ for 10 minutes at $4^{\circ} \mathrm{C}$. Plasma was discarded and the erythrocytes were incubated in $40 \%$ Glycerol solution (Formule 548 - INTS, Paris, France) at a 
volume ratio of $1: 2$, for 10 minutes and then transferred to cryogenic $0.5 \mathrm{~mL}$ straws (Cryo Bio System, Saint Ouen sur Iton, France). Glycerol is an attractive red blood cell cryoprotective agent because it is relatively nontoxic at high concentrations and it readily permeates the cell at $37^{\circ} \mathrm{C}$ (Scott, et al., 2005). The blood was subjected to a slow cryopreservation process in the Freezal freezing machine (Air Liquide ${ }^{\mathrm{TM}}$, Paris, France) in order to prevent excessive cell volume reduction and the lethal concentration of electrolytes and to prevent inappropriate formation of ice crystals which can cause rupture of the red blood cells (Scott, et al., 2005; Stolzing A, et al., 2012). The freezing curve has been standardized after several tests in which, besides different rates of temperature decline having been applied, two parameters have been considered post-thawing of the tested samples: calculation of the free hemoglobin concentration and visual classification of hemolysis. The adopted curve consists of two stages of freezing speed: $1^{\text {st }}$ ) from 5 to $-40^{\circ} \mathrm{C}$ (decline of $1^{\circ} \mathrm{C} /$ minute) and $2^{\text {nd }}$ ) from $-40^{\circ} \mathrm{C}$ to $-100^{\circ} \mathrm{C}$ (decline of $10^{\circ} \mathrm{C} /$ minute). After this procedure, the samples were stored in liquid nitrogen $\left(-196^{\circ} \mathrm{C}\right)$ for later use in the Adhesion Assay described below.

Once thawed, the blood samples were diluted in $10 \%$ Glycerol solution (Formule 534 - INTS, Paris, France) at a volume ratio of 1:3 and centrifuged at $2500 \mathrm{rpm}$ for 10 minutes at $4^{\circ} \mathrm{C}$. After the supernatant was discarded and the red blood cell pellet was resuspended in 8\% (1:3) Sorbitol solution (Formule 533INTS, Paris, France), further centrifugation under the same conditions was performed. The pellet of red blood cells was then sequentially washed in $0.9 \%$ physiological solution (JP Indústria Farmacêutica S.A., Ribeirão Preto, Brazil) and centrifuged 5 times before being resuspended in a stabilizing formulated glycine buffered saline (ID-Cell Stab, BioRad®, Lagoa Santa, Brazil) at a 
concentration of $0.8 \%$. Samples were then stored overnight at $4^{\circ} \mathrm{C}$, ready to be used in the Cell Adhesion Assay in the following day.

\subsection{Pitted cells counting}

One of the ways to assess the splenic function loss is to quantify the circulating erythrocytes that present depressions in their cell membranes, the so called pitted cells, which, under normal physiological conditions, appear gradually in higher frequency as the cells age and, under pathophysiological conditions, appear on a larger scale due to splenic dysfunction. For each sample, two drops of fresh blood were fixed immediately after its collection in $0.3 \mathrm{~mL}$ of $3 \%$ formaldehyde in buffered solution, at $\mathrm{pH} 7.4$. After 30 minutes, one drop of the material has been transferred to a slide and covered with a coverslip for observation under a microscope with immersion oil, magnification of $x 63$. Five hundred cells per patient were evaluated and the percentage of cells that had one or more depressions was quantified. Images of pitted cells were also recorded by the microscope software. The erythrocytes have been analyzed with Normasky's Microscopy or Differential Interference Contrast Microscopy - DIC (Axio Observer A1 - Carl Zeiss ${ }^{\circledR}$, Jena, Germany).

\subsection{Howell-Jolly bodies counting}

Howell-Jolly bodies (HJB) are nuclear remnants presented in circulating red blood cells which have not been properly removed by the spleen (Brousse et al., 2014). For quantification of the frequency of red cells that contain such remnants, fresh blood smears previously collected in EDTA were analyzed with immersion oil (x100) under light microscopy after May-Grünwald and Giemsa staining (Lewis et al., 2006). Ten microscopic fields were considered for each 
blood smear, with 100 erythrocytes analysed in each field, in order to obtain an estimate of the cell percentage with HJB in a sample of 1000 erythrocytes per patient. After quantification, images of cells with $\mathrm{HJB}$ were performed on a microscope equipped with a digital camera in the AxioVision ${ }^{\mathrm{TM}}$ software (Axio Observer A1 - Carl Zeiss $®$, Jena, Germany).

\subsection{Cellular immunophenotyping}

Immunophenotyping of erythrocytes and reticulocytes was carried out on blood samples collected after 60 hours of storage at $4^{\circ} \mathrm{C}$ in stabilizing formulated glycine buffered saline at $0.8 \%$. The red blood cells concentrate was diluted in $0.2 \%$ BSA PBS solution and incubated with primary antibodies (ABs) against the surface molecules IgG, CD36, CD44, CD47, CD49d, CD58, CD99, CD108, CD147, CD151, CD239 (LuBCAM) and CD242, for 60 minutes at room temperature (RT). Excess of $A B$ was removed with two washes at $1200 \mathrm{rpm}$ for 3 minutes at RT. Secondary ABs conjugated with phycoerythrin (PE) fluorophore were used to label the primary antibodies at a 1/150 dilution, for 45 minutes at RT in the dark. Further washes were performed and all tubes containing the above-mentioned antibodies were later labeled with ReticCount ${ }^{\mathrm{TM}}$ reagent (thiazole orange) (BD Biosciences $®$, San Jose, USA), for 30 minutes at RT in the dark, for further analysis of the mean intensity fluorescence (MFI) and of the reticulocytes and red blood cells frequency of expressing the adhesion molecules adopted in this study. FACSDiva ${ }^{\mathrm{TM}}$ flow cytometer (BD Biosciences ${ }^{\circledR}$, San Jose, USA) was used to analyse the results, using FACSDiva Version 6.1.1 software (BD Biosciences ${ }^{\circledR}$, San Jose, EUA) for acquisiton of data, in order to eliminate possible cell agregates or doublets presented in the samples, which could 
generate false-positive results. Furthermore, on the day of each collection, $5 \mu \mathrm{L}$ of fresh blood from each patient were labeled with $1 \mathrm{~mL}$ of ReticCount ${ }^{\mathrm{TM}}$, for 30 minutes in the dark at RT, in order to determine the percentage of reticulocytes in the total human peripheral blood analyzed. These samples were processed on

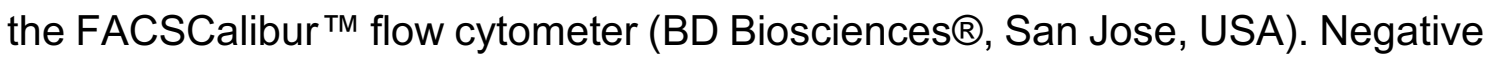
controls were performed both for antibody labeling and for ReticCount ${ }^{\mathrm{TM}}$ labeling. Both systems were calibrated for the evaluation of at least 10,000 events in each determination.

\subsection{Cellular adhesion assay}

\subsubsection{Expansion of the HMEC-1 lineage}

Transfected human dermal microvascular endothelial cells (HMEC-1) (ATCC, Chicago, USA) were grown in Molecular, Cellular and Developmental Biology (MCDB) 131 medium (Sigma-Aldrich, St. Louis, USA) supplemented with $10 \mathrm{ng} / \mathrm{mL}$ of epidermal growth factor (EGF) (Peprotech, Rocky Hill, USA), 1 $\mu \mathrm{g} / \mathrm{mL}$ of hydrocortisone (Sigma-Aldrich, St. Louis, USA), $10 \mathrm{mM}$ of glutamine (Gibco ${ }^{\mathrm{TM}}$, Grand Island, USA), 10\% of fetal bovine serum (FBS) (Hyclone, Logan, USA), $100 \mathrm{U} / \mathrm{mL}$ of penicillin (Sigma, Steinheim, Germany) and $100 \mu \mathrm{M}$ of streptomycin (Sigma, Steinheim, Germany) at pH 7.4.

Cells were maintained in a humidified incubator, with HEPA grade 100 filter (Thermo Electron Corporation, Marietta, USA), at $37^{\circ} \mathrm{C}$ and $5 \% \mathrm{CO}_{2}$ and manipulated in vertical laminar flow (Thermo Electron Corporation, Marietta, USA). Once having reached about $80 \%$ of confluency, the endothelial cells were washed twice with PBS. Then, enzymatic cleavage has been performed with $0.025 \%$ trypsin solution (Sigma, Steinheim, Germany) with $0.5 \mathrm{mM}$ of EDTA and 
$1 \mathrm{mM}$ of sodium pyruvate (Sigma, St. Louis, USA) for 5 minutes. Cells detached from the plastic bottles were resuspended in RPMI with 10\% FBS, centrifuged at $1200 \mathrm{rpm}$ for 10 minutes at RT and seeded into Vena Flux Endothelial+ ${ }^{\mathrm{TM}}$ biochips with eight parallel microcapillaries $0.8 \mathrm{~mm}$ wide (Cellix®, Dublin, Ireland) at a concentration of $2 \times 10^{7}$ cells $/ \mathrm{mL}$ in $20 \mu \mathrm{l}$ of complete MCDB131 medium in each biochip channel. Such channels had been previously pretreated with 0.1 $\mathrm{mg} / \mathrm{mL}$ type I collagen (Corning ${ }^{\circledR}$, Wiesbaden, Germany) for at least 15 minutes at $37^{\circ} \mathrm{C}$. Seeded channels with HMEC-1 were incubated for 2 hours before being connected to the closed Kima pump system (Cellix®, Dublin, Ireland).

\subsubsection{Treatment with laminin}

In the meantime, while the microcapillaries were seeded with HMEC-1, others were treated with $20 \mu \mathrm{l}$ of laminin solution (Biolamine, Stockholm, Sweden) in each channel, at $10 \mu \mathrm{g} / \mathrm{mL}$ overnight in a humid chamber at $4^{\circ} \mathrm{C}$. On the day of the experiment, each laminin-treated channel was saturated with a $0.5 \% \mathrm{BSA}$ solution in PBS, one hour prior to the experiment, in order to avoid non-specific binding between endothelial cells and red cells receptors.

\subsubsection{Adhesion assay preparation}

The Dynamic Adhesion Platform is a tool that allows the user to mimic venous and arterial physiological flow and blood shear stress by means of a system that includes the biochips with microcapillaries previously mentioned and a set of microfluidic syringe pumps (ExiGo ${ }^{\mathrm{TM}}$, Cellix ${ }^{\circledR}$, Dublin, Ireland) controlled by a LabVIEW interface with the aid of Exigo ${ }^{\mathrm{TM}}$ flow sensors (Cellix ${ }^{\circledR}$, Dublin, Ireland) (Cooke et al., 1993). 
After 2 hours of incubation at $37^{\circ} \mathrm{C}$, the biochip coated with HMEC- 1 cells was connected to the Kima pump, which allows the intermittent pumping of culture medium onto the endothelial cells. Its running is carried out via wireless connection to an iPod Touch whose iKima application has been programmed to execute the flow of culture medium in two steps: $1^{\text {st) }}$ flow rate of $600 \mu \mathrm{L} /$ minute and perfusion time of 30 seconds; $2^{\text {nd }}$ ) without flow for 40 minutes. After 8 hours of incubation, TNF- $\alpha$ at a concentration of $5 \times 10^{-3} \mu \mathrm{g} / \mathrm{mL}$ was added to the system, in order to promote activation of endothelial cells. The cells remained a total of 24 hours connected to the Kima pump.

On the experiment day, biochips previously seeded with HMEC-1 or treated with laminin were taken to the Adhesion Platform microscope where they were connected to the syringe pump system and its sensors. Such sensors allow the user to precisely dispense a certain volume of liquid at specific flow rates into the capillaries. Channels treated with HMEC-1 cells remained at a temperature of $37^{\circ} \mathrm{C}$.

\subsubsection{Blood sample preparation}

On the experiment day, the red cell pellet previously thawed, washed and stored in ID-Cell Stab has been washed again twice with physiological solution and diluted in $1 \mathrm{~mL}$ of Hanks Balanced Salt Solution (Sigma, St. Louis, USA) containing $3.7 \mathrm{~g} / \mathrm{L}$ of sodium bicarbonate (Sigma, St. Louis, USA), $10 \mathrm{mM}$ of 4(2-hydroxyethyl)-1-piperazinethanesulfonic acid (HEPES) (Sigma, St. Louis, USA), $100 \mathrm{U} / \mathrm{mL}$ of penicillin, $100 \mu \mathrm{M}$ of streptomycin, $0.5 \mathrm{M}$ of calcium chloride (Sigma-Aldrich, St. Louis, USA), 0.5 M of magnesium chloride (Sigma-Aldrich, St. 
Louis, USA) and $0,4 \%$ of human serum albumin (HSA) (Vialebex®, Lille, France) at $\mathrm{pH} 7.4$.

In order to observe the red cell adhesion ability to laminin, the blood pellet was diluted to a Htc of $0.5 \%$ and for the channels seeded with HMEC-1, blood was diluted to $1 \%$ Hct. The biochip was then fed on one side by the diluted blood sample and aspirated on the other side by the sensor-controlled microfluidic syringe pump system. Each patient sample has been run in duplicate for the two cell adhesion conditions at six different and progressively higher rates $(0.5,1,2$, 3, 5 and 7 dyne/cm ${ }^{2}$ ), according to the program shown in Figure 1. Such program consisted of two steps: $1^{\text {st }}$ ) Perfusion, in which red blood cells flow remained at 0.5 dyne $/ \mathrm{cm}^{2}$ for 15 minutes and $2^{\text {nd }}$ ) Wash, in which the other mentioned speeds were applied for 5 minutes each. A photograph was recorded at each speed adopted, in six representative areas along the biochip channel, by using AxioVision ${ }^{\mathrm{TM}}$ software (Carl Zeiss ${ }^{\circledR}$, Jena, Germany) so that adhered cells to laminin or to HMEC-1 endothelial cells could be quantified later with the aid of the same software. 


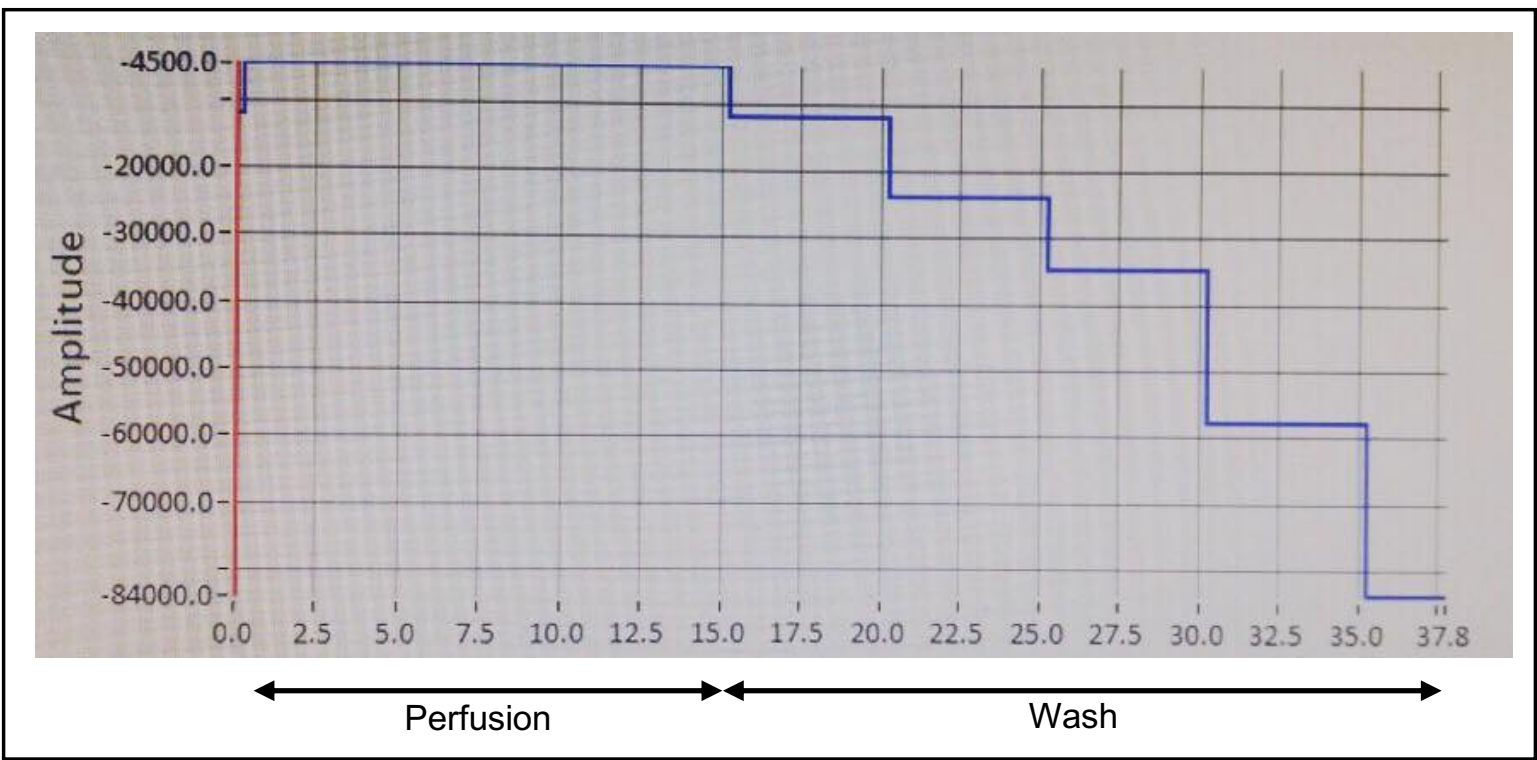

Figura 1. Cell Adhesion Assay curve. Illustration of the adopted program for the collected blood samples, consisting of two steps: 1) Perfusion - 0.5 dyne $/ \mathrm{cm}^{2}$ for 15 minutes and 2) Wash successive increase of speed every 5 minutes at flow rates $1,2,3,5$ and 7 dynes $/ \mathrm{cm}^{2}$. Axis $x$ represents the time, in minutes.

\subsection{Statistical analysis}

Statistical analysis was performed using GraPhpad Prism version 7.00 software (GraphPad Software, La Jolla, USA). For evaluation of the proportional relation between the percentage of pitted cells, cells with $\mathrm{HJB}$ and patients age, Spearman's non-parametric linear correlation test has been applied. Evaluation of median between the compared conditions and the calculation of the descriptive statistics, containing the subjects hemolysis data, have been performed by applying the non-parametric Mann-Whitney test and data are expressed as [Median \pm (Interquartile Interval)]. Also, the former test was used for further quantitative analysis. Findings obtained for the Immunophenotypic Assay are shown as percentage and MFI expression. Cell Adhesion Assay contains data expressed as adherent RBCs/mm². Differences have been considered significant when $\mathrm{p}<0.05$. 


\section{RESULTS AND DISCUSSION}

\subsection{Splenic function quantification}

5.1.1 Splenic function quantification in SCA children between 6 to 29 months

HJB and vacuoles on the red blood cell surface (PIT) are known cellular characteristics that make it possible to evaluate the filtering and cleaning function of old or defective circulating cells performed by the spleen. Literature findings indicate that a percentage greater than or equal to $3.5 \%$ of pitted cells is indicative of splenic dysfunction (Pearson, et al., 1985). In its turn, values higher than $0.03 \%$ of cells containing HJB corpuscles were associated with loss of splenic filtration function (Rogers et al., 2011).

In the present study, the follow-up study of the pitted cells percentage $(r=$ $0.6, p=0.006)$ and those with HJB $(r=0.5, p=0.01)$ showed that the splenic function slightly decreased as the first months of life passed in the SCA group with patients between 6 and 29 months of life (Figure 2). 


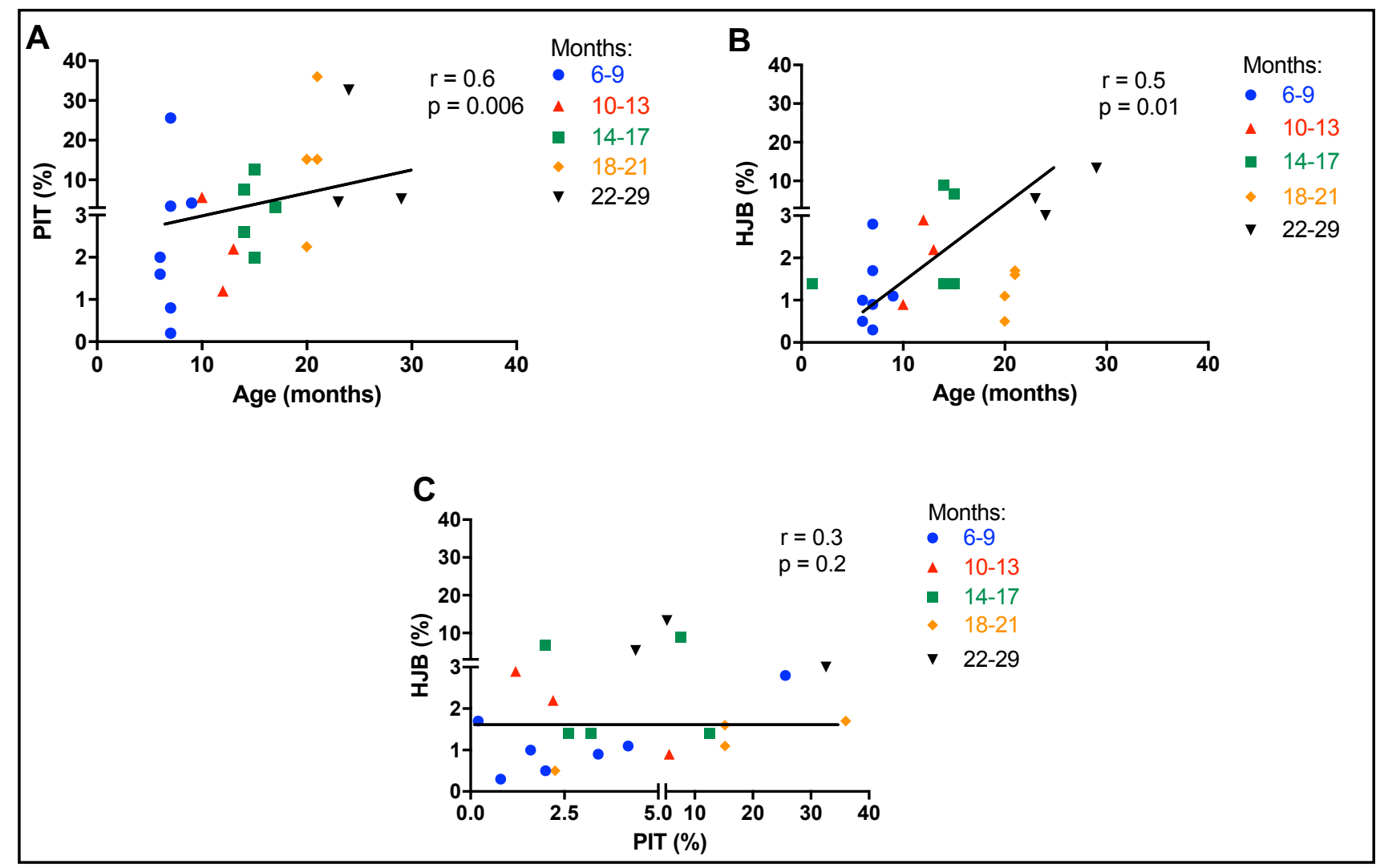

Figure 2. Quantification of splenic dysfunction in SCA patients between 6 and 29 months of age. (A) Correlation between the percentage of pitted cells (\%) and the aging of patients. (B) Correlation between the number of circulating red cells with HJB (\%) and age (months). (C) Correlation between HJB and PIT (\%). N = 22. Spearman non-parametric linear correlation test. PIT = pitted cells.

\subsubsection{Splenic function quantification in SCA subjects from 3 years of life on and in HS subjects}

When the aforementioned SCA group with individuals up to 29 months of age was compared to SCA patients 3 years old or older, there was a significant decrease in splenic function in the last group (PIT: $r=0.8, p<0,0001$ and HJB: $r$ $=0.7, p<0.0001)$ (Figure 3A-B). Still, HJB counting and PIT counting correlation was significant $(r=0.5 ; p=0.001)$ (Figure $3 C)$. Also, there was a significant correlation between HJB counts and PIT counts $(r=0.5 ; p=0.001)$ in SCA patients 3 years old or older, in accordance with previous findings (Corazza, et al., 1990). 


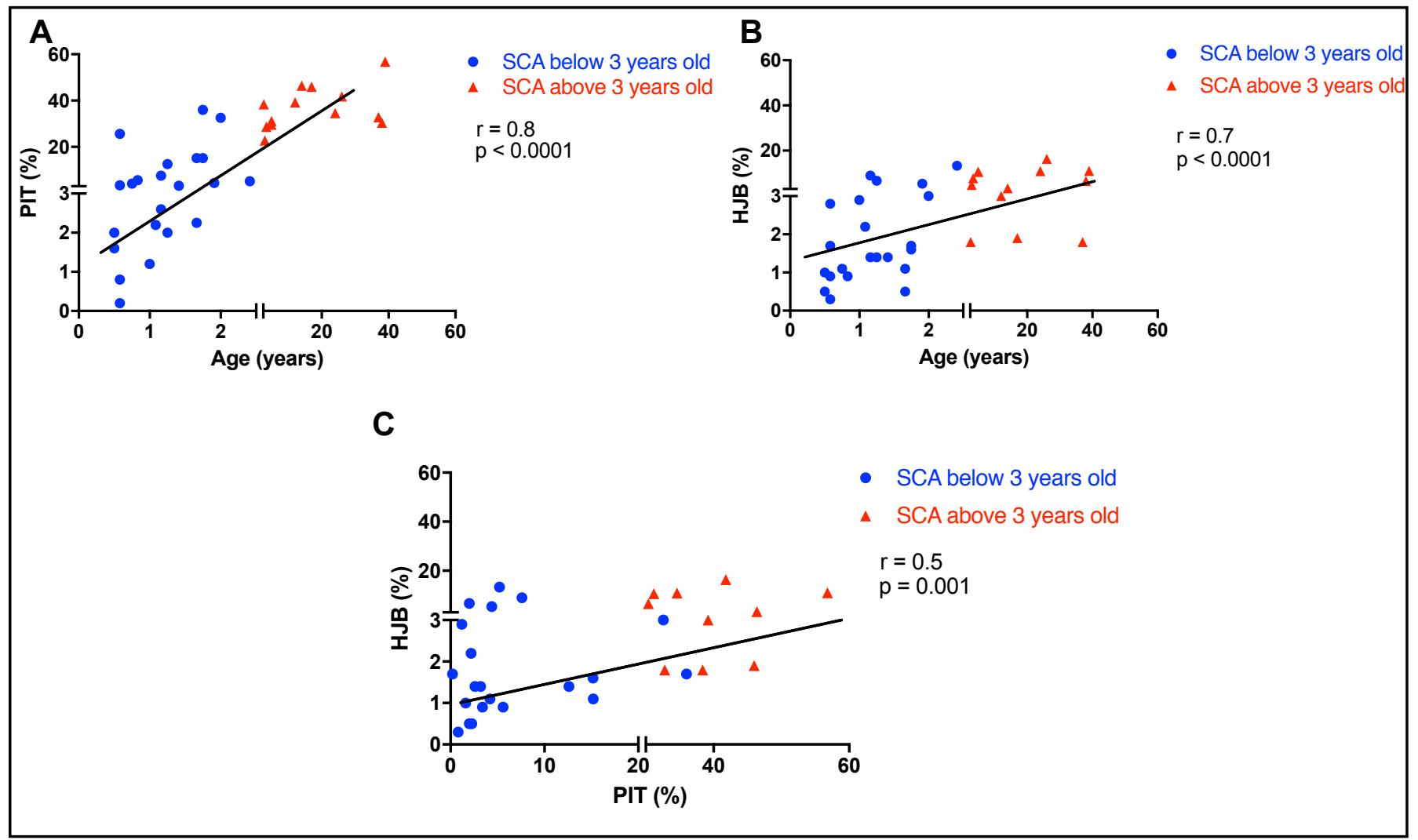

Figure 3. Quantification of splenic dysfunction in SCA patients with and without preserved splenic function. (A) Correlation of the percentage of pitted cells versus the age of SCA patients with $(n=22)$ and without $(n=13)$ preserved splenic function. (B) Correlation between the number of circulating red cells with HJB (\%) and aging in SCA patients. (C) Correlation between the splenic markers HJB and PIT (\%). Spearman non-parametric linear correlation test. PIT = pitted cells.

HS patients, on the other hand, did not present correlation of the percentage levels of these two biomarkers of splenic dysfunction in relation to their aging (PIT: $r=-0.04 ; p=0.8$ and HJB: $r=0.2 ; p=0.3$ ), although the correlation between the two markers was positive and proportional $(r=0.6, p=$ 0.002) (Figure 4). Figure 5 illustrates the morphology of quantified circulating PIT and HJB cells in representative patients. 


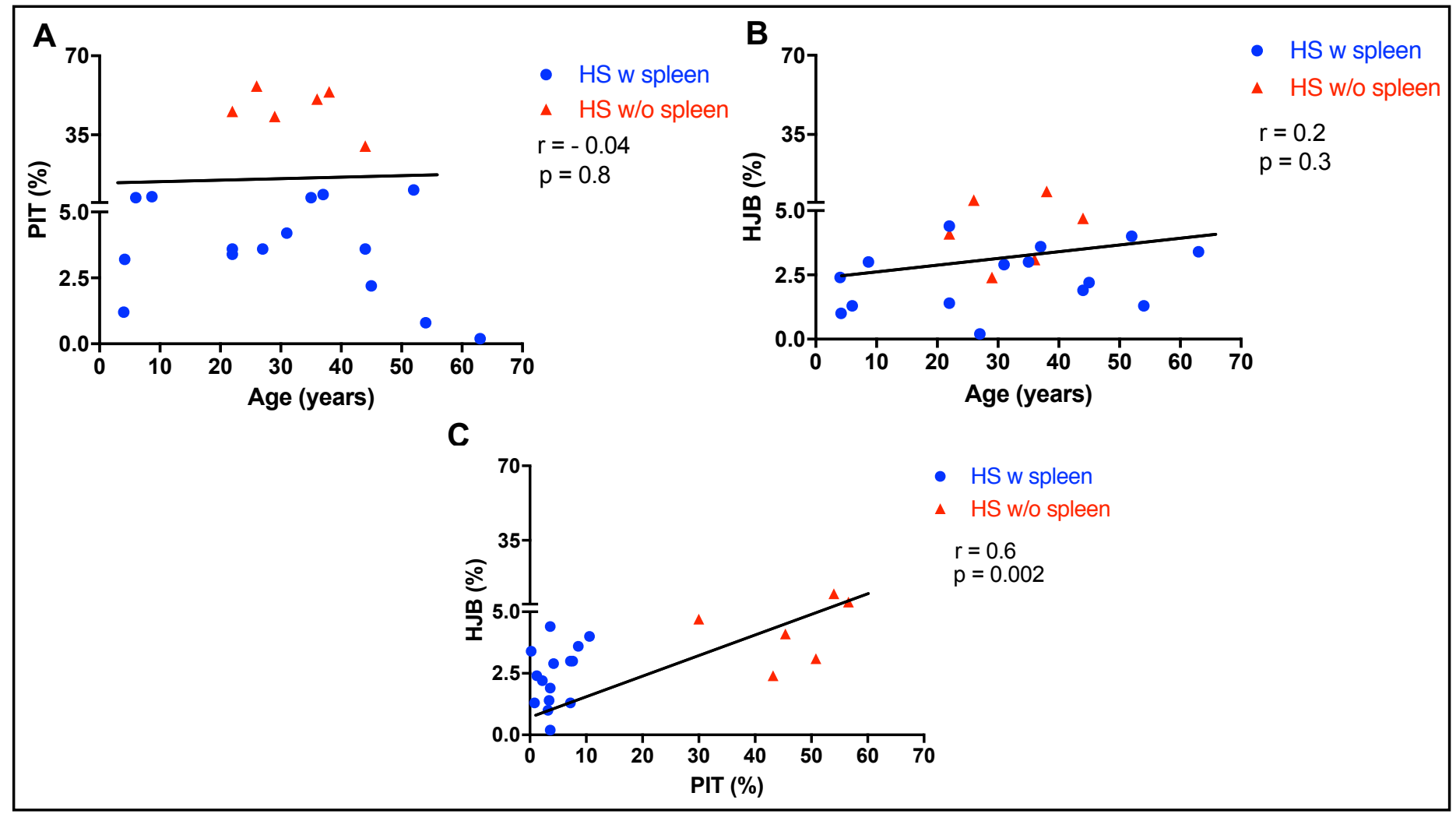

Figure 4. Quantification of splenic dysfunction in HS patients with and without spleen. (A) Correlation of percentage of pitted cells versus age of HS patients with spleen $(n=15)$ and splenectomized $(n=6)$. (B) Correlation between the number of circulating red cells with HJB (\%) and aging in HS patients. (C) Correlation between the splenic markers HJB and PIT (\%). Spearman non-parametric linear correlation test. PIT = pitted cells. 


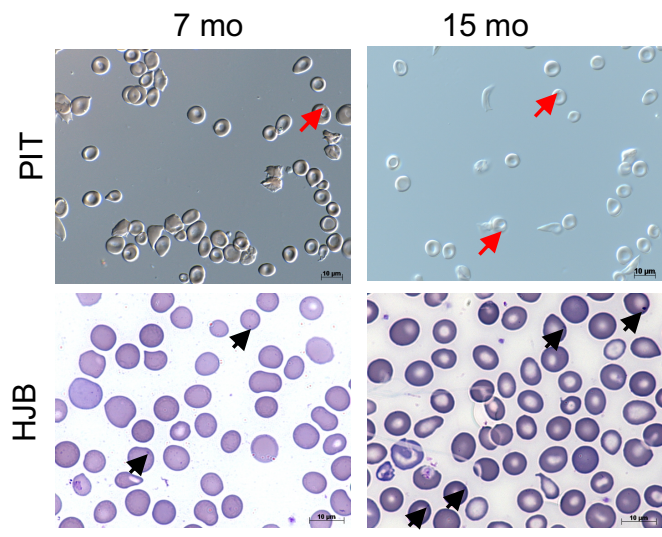

Splenic function loss transition

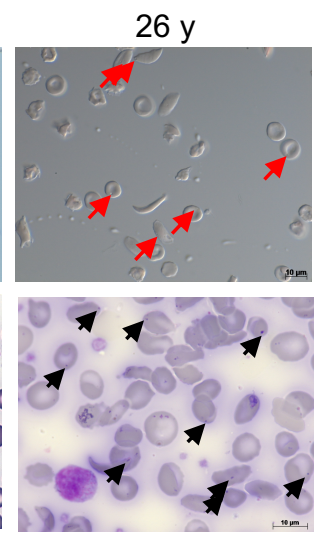

Without splenic function

$$
\text { SCA }
$$

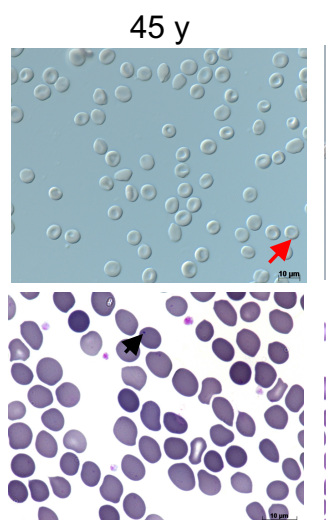

With spleen
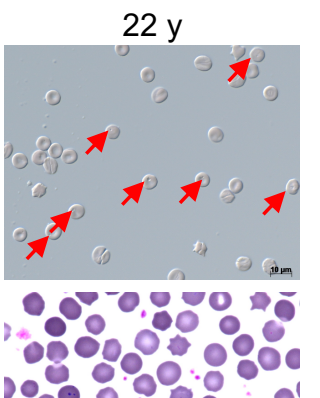

10090.900

\%8.

Without spleen

HS

Figure 5. Morphology of pitted cells and HJB cells in SCA and HS samples. In the three left columns, photomicrographs of reticulocytes and erythrocytes of SCA patients at 7 months (PIT = $0.8 \%, \mathrm{HJB}=0.3 \%), 15$ months $(\mathrm{PIT}=2 \%, \mathrm{HJB}=6.7 \%)$ and 26 years $(\mathrm{PIT}=41.8 \%, \mathrm{HJB}=$ $16.4 \%$ ), respectively. The two columns on the right show the cells of a 45 year-old (PIT $=2.2 \%$, $\mathrm{HJB}=2.2 \%$ ) and a 22 year-old $\mathrm{HS}$ individuals $(\mathrm{PIT}=45.4 \%, \mathrm{HJB}=4.1 \%)$, respectively. $\mathrm{mo}=$ months; $y=$ years. Red arrows point to vacuoles in cell membrane (PIT) and black arrows show HJB.

\subsubsection{Markers of hemolysis and splenic function loss}

Some clinical signs are also predictive of an anemic state and of splenic function loss, and are thus considered markers of hemolysis (Zago, et al., 2013).

As shown in Table 1, of the hemolysis markers compiled in this study, levels of indirect bilirubin [1.61 $(1.15-3.5) \mathrm{mg} / \mathrm{dL} ; \mathrm{p}=0.01]$ and platelets [484 $(411.5-706.5) \times 103 / \mu \mathrm{l} ; \mathrm{p}<0.03)$ were higher in asplenic SCA patients in comparison to subjects with preserved splenic function [1.02 (0.5 - 1.5) mg / dL; $p=0.01]$ and $[387.5(324.5-462.5) \times 103 / \mu L ; p<0.03]$, respectively. On the other hand, despite the important function of the spleen in cleaning defective circulating cells, splenectomy in HS patients, as a general rule, decreases the levels of some important markers of hemolysis in the circulation, improving certain pathophysiological aspects of the disease (An and Mohandas, 2008). In fact, the data analyzed in this study demonstrated that circulating reticulocytes [2.36 (1.25 - 3.0) \%; $p=0.03]$, indirect bilirubin levels [0.5 (0.3 - 1.35) mg / dL; $p$

$=0.01]$, $]$ and $\operatorname{LDH}[300.5(283-333) \cup / \mathrm{L} ; \mathrm{p}=0.0003]$ decreased in 
splenectomized HS patients compared to those with spleen: [Ret $=6.8(2.3-$ 10.5)\%; $p=0.03],[\mathrm{IB}=2.45(1.3-3.7) \mathrm{mg} / \mathrm{dL} ; \mathrm{p}=0.01]$, and [LDH $=479$ (373 - 634) U / L; $p=0.0003$ ] (Table 1).

Table 1. Markers of hemolysis and clinical data. The values are expressed in [median (interquartile range)], according to the Mann-Whitney non-parametric test.

\begin{tabular}{|c|c|c|c|c|c|}
\hline & $\begin{array}{l}\text { SCA with preserved } \\
\text { splenic function }\end{array}$ & $\begin{array}{c}\text { SCA without } \\
\text { preserved splenic } \\
\text { function }\end{array}$ & HS with spleen & $\begin{array}{l}\text { HS without } \\
\text { spleen }\end{array}$ & $p$ value \\
\hline Pacients (n) & 22 & 12 & 15 & 6 & - \\
\hline $\begin{array}{c}\text { Age (years) } \\
\text { [median (IQR)] }\end{array}$ & $1.16(0.6-1.7)^{\star}$ & $14(4.2-31.5)$ & $31(8.66-45)$ & $32.5(25-39.5)$ & ${ }^{*} p<0.0001$ \\
\hline $\begin{array}{c}\mathrm{Hb}(\mathrm{g} / \mathrm{dL}) \\
{[\text { median (IQR)] }}\end{array}$ & $9.2(8.3-9.4)$ & $8.5(8.2-9.3)$ & $\begin{array}{c}11.3(10.2- \\
12.1)^{*}\end{array}$ & $\begin{array}{c}14.6(13.7- \\
17.2)^{*}\end{array}$ & ${ }^{*} p=0.001$ \\
\hline $\begin{array}{c}\text { Reticulocyte } \\
(\%) \\
\text { [median (IQR)] }\end{array}$ & $8.4(4.8-17.3)$ & $9.1(6.0-20.6)$ & $6.8(2.3-10.5)^{\star *}$ & $2.36(1.25-3.0)^{\star *}$ & ${ }^{* *} p=0.03$ \\
\hline $\begin{array}{c}\text { Indirect } \\
\text { bilirubin } \\
\text { (mg/dL) } \\
\text { [median (IQR)] }\end{array}$ & $1.02(0.5-1.5)^{\star \star *}$ & $1.61(1.15-3.5)^{* * *}$ & $\begin{array}{c}2.45(1.3- \\
3.7)^{\star * * *}\end{array}$ & $\begin{array}{l}0.5(0.3- \\
1.35)^{\star \star \star * \star}\end{array}$ & $\begin{array}{l}* * * p=0.01 \\
* * * * p=0.01\end{array}$ \\
\hline $\begin{array}{c}\text { LDH (U/L) } \\
\text { [median (IQR)] }\end{array}$ & $771(648-1125)$ & $879(571-1298)$ & $479(373-634) \dagger$ & $\begin{array}{c}300.5(283- \\
333) \dagger\end{array}$ & $+p=0.0003$ \\
\hline $\begin{array}{c}\text { HbF (\%) } \\
\text { [median (IQR)] }\end{array}$ & $23.5(17.1$ - 26.5)†† & $12.8(9.0$ - 15.8)†† & - & - & $\dagger † p=0.0084$ \\
\hline $\begin{array}{l}\text { Platelet }\left(10^{3} / \mathrm{uL}\right) \\
\text { [median (IQR)] }\end{array}$ & $\begin{array}{c}387.5(324.5- \\
462.5)++\end{array}$ & $\begin{array}{l}484(411.5- \\
706.5)++\end{array}$ & $\begin{array}{c}249(164- \\
300) \div\end{array}$ & $\begin{array}{c}488.5(377- \\
638.3)+\end{array}$ & $\begin{array}{l}++p<0.03 \\
+p=0.0004\end{array}$ \\
\hline $\begin{array}{l}\text { Hematocrit (\%) } \\
\text { [median (IQR)] }\end{array}$ & $28(26-30)$ & $26(24.5-28.5)$ & $32(29-34) \S$ & $\begin{array}{c}42.5(38.8- \\
47.25) \S\end{array}$ & $\S p=0.002$ \\
\hline
\end{tabular}

$\mathrm{IQR}=$ interquartile range; $\mathrm{Hb}=$ hemoglobin; $\mathrm{LDH}=$ lactate dehydrogenase; $\mathrm{HbF}=$ fetal hemoglobin.

In this study, the intensity of splenic dysfunction was also inversely proportional to the amount of $\mathrm{HbF}$ in the red blood cells of SCA patients. Thus, as spleen's phagocytic protective function gradually decreased, peripheral circulation of HbF levels declined $(r=-0.65 ; p<0.0001)$ (Figure 6), reflecting 
what is commonly observed in the SCA pathophysiology (Maier-Redelsperger et al., 1994).

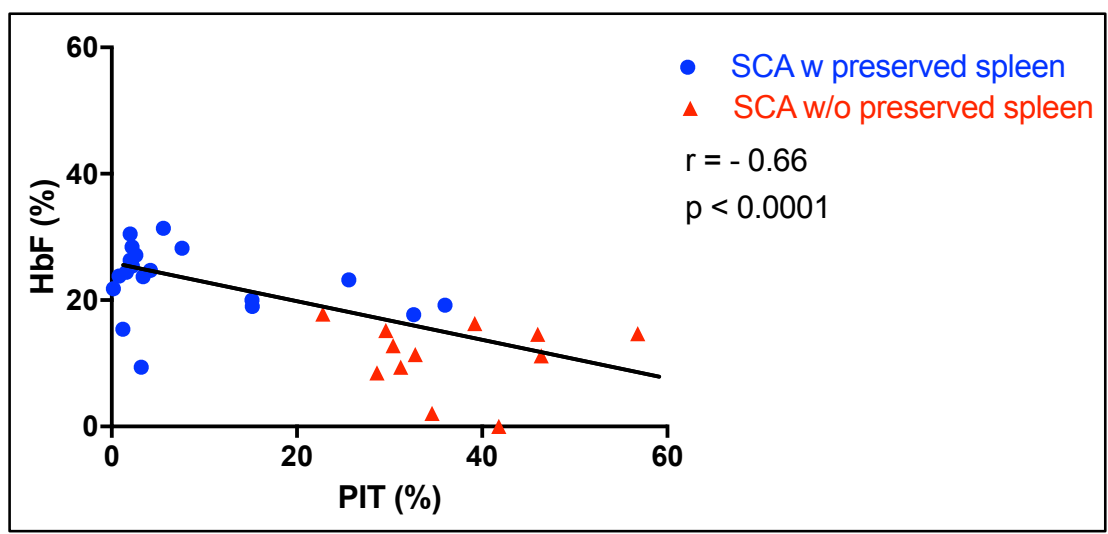

Figure 6. Correlation between splenic function and $\mathrm{HbF}$ serum levels in SCA patients with and without spleen. Negative correlation of pitted cell percentage versus $\mathrm{HbF}$ percentage in SCA patients with $(n=19)$ and without $(n=12)$ preserved splenic function. Spearman nonparametric linear correlation test.

\subsection{Cellular immunophenotyping}

\subsubsection{Adhesion markers versus PIT counting comparison}

Of the two biomarkers of splenic function evaluated in this study, PIT counting showed a higher correlation directly proportional to the aging of the patients (Figure 3). In fact, PIT counting represent a more sensitive method for evaluation of splenic function (Corazza, et al., 1990). Thus, the study objective in this new phase was to investigate whether the splenic function loss would be correlated with the increase of circulating adhesive reticulocytes and erythrocytes in SCA and HS patient samples.

The immunophenotypic expression analysis in this study used 11 surface markers normally adopted to characterize reticulocytes and red blood cells regarding their adhesive profile. The correlation of the pitted cell percentage versus the frequency and versus the MFI expression on the surface of reticulocytes and erythrocytes regarding each adhesion markers was compared. 
When evaluating the amount of adhesive epitopes expressed on the reticulocyte and erythrocyte membrane, we observed higher frequency and higher MFI for the markers CD147, LuBCAM and CD58 in SCA patients with no splenic function compared to patients with preserved splenic function (Figures 79, A-D top), confirming the prominent adhesive role of these molecules in the interaction with the activated endothelium and the pro-thrombotic phenotype observed in SCA, at the same time that highlights the importance of the splenic activity in controling the adhesive phenotype of some adhesion markers in patients with SCA (EI Nemer, et al., 2008, Rees, et al., 2010, El Nemer, et al., 2010).

Both types of HS samples, with and without spleen, haven't differed in frequency or MFI expression for CD147, LuBCAM and CD58 (Figures 7-9, A-D bottom). 

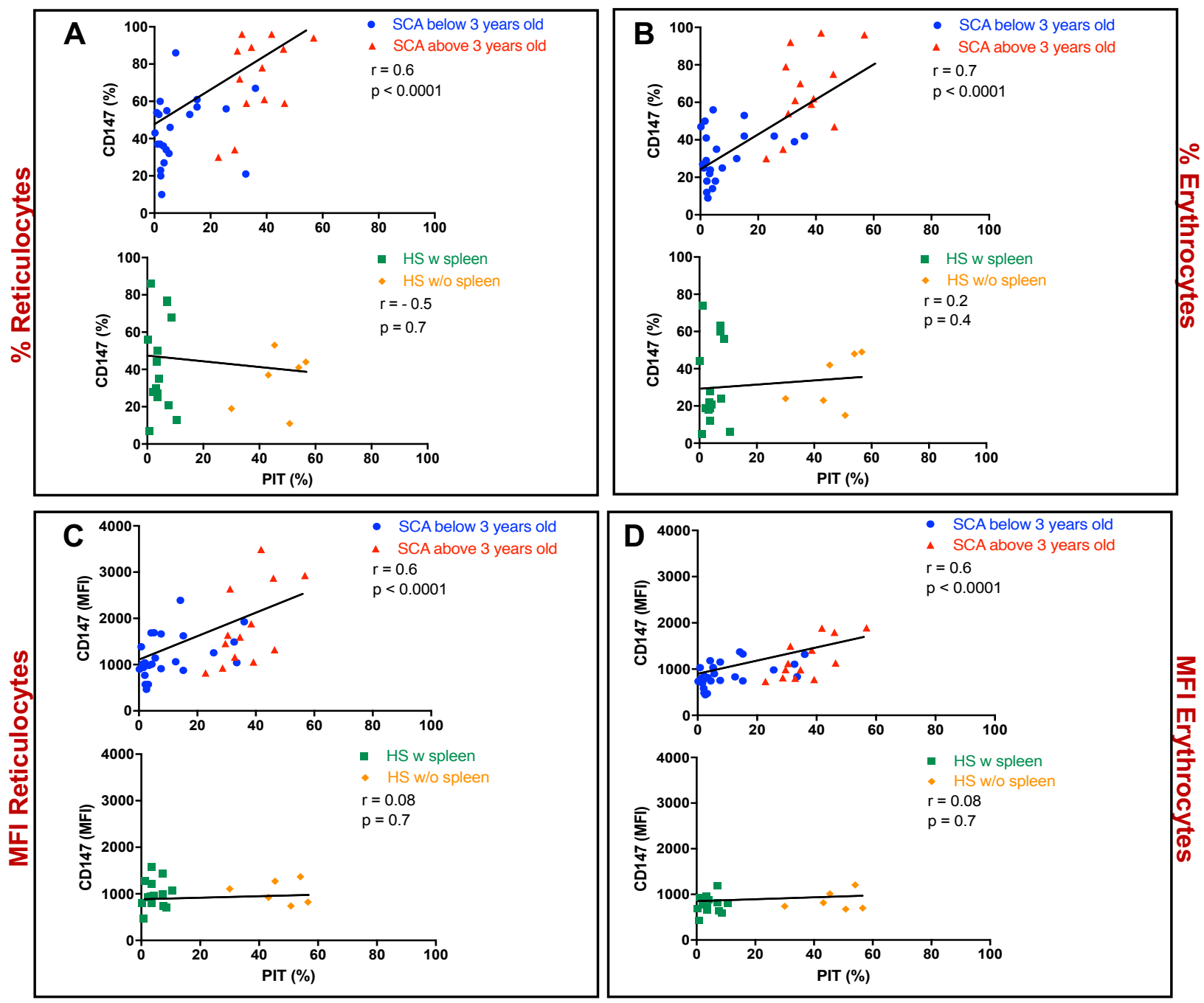

Figure 7. Correlation between CD147 and splenic function loss. (A-B) Frequency of reticulocytes (A) and erythrocytes (B) positive for CD147 in relation to the splenic function quantification (PIT) in SCA patients with $(n=22)$ and without $(n=13)$ preserved splenic function (top) and in HS patients with $(n=15)$ and without $(n=6)$ spleen (bottom). (C-D) Correlation between CD147 MFI expression in reticulocytes (C) and erythrocytes (D) and PIT counting in SCA (top) and HS (bottom) patients. Spearman non-parametric linear correlation test. 

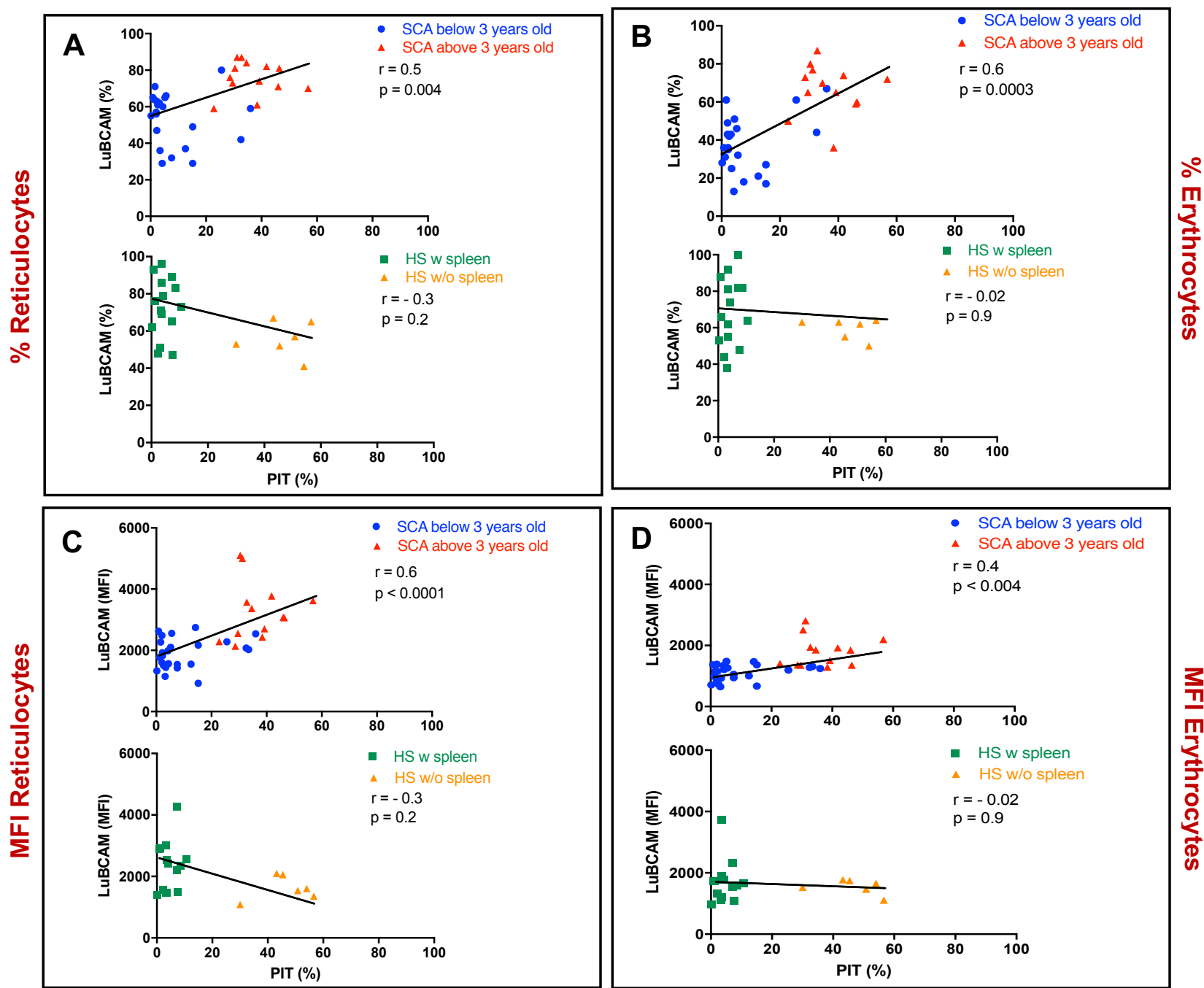

Figure 8. Correlation between LuBCAM and splenic function loss. (A-B) Frequency of reticulocytes (A) and erythrocytes (B) positive for LuBCAM in relation to the splenic function quantification (PIT) in SCA patients with preserved splenic function $(n=22)$ and and without $(n=$ 13) preserved splenic function (top) and in HS patients with $(n=15)$ and without $(n=6)$ spleen (bottom). (C-D) Correlation between LuBCAM MFI expression in reticulocytes (C) and erythrocytes (D) and PIT counting in SCA (top) and HS (bottom) patients. Spearman nonparametric linear correlation test. 

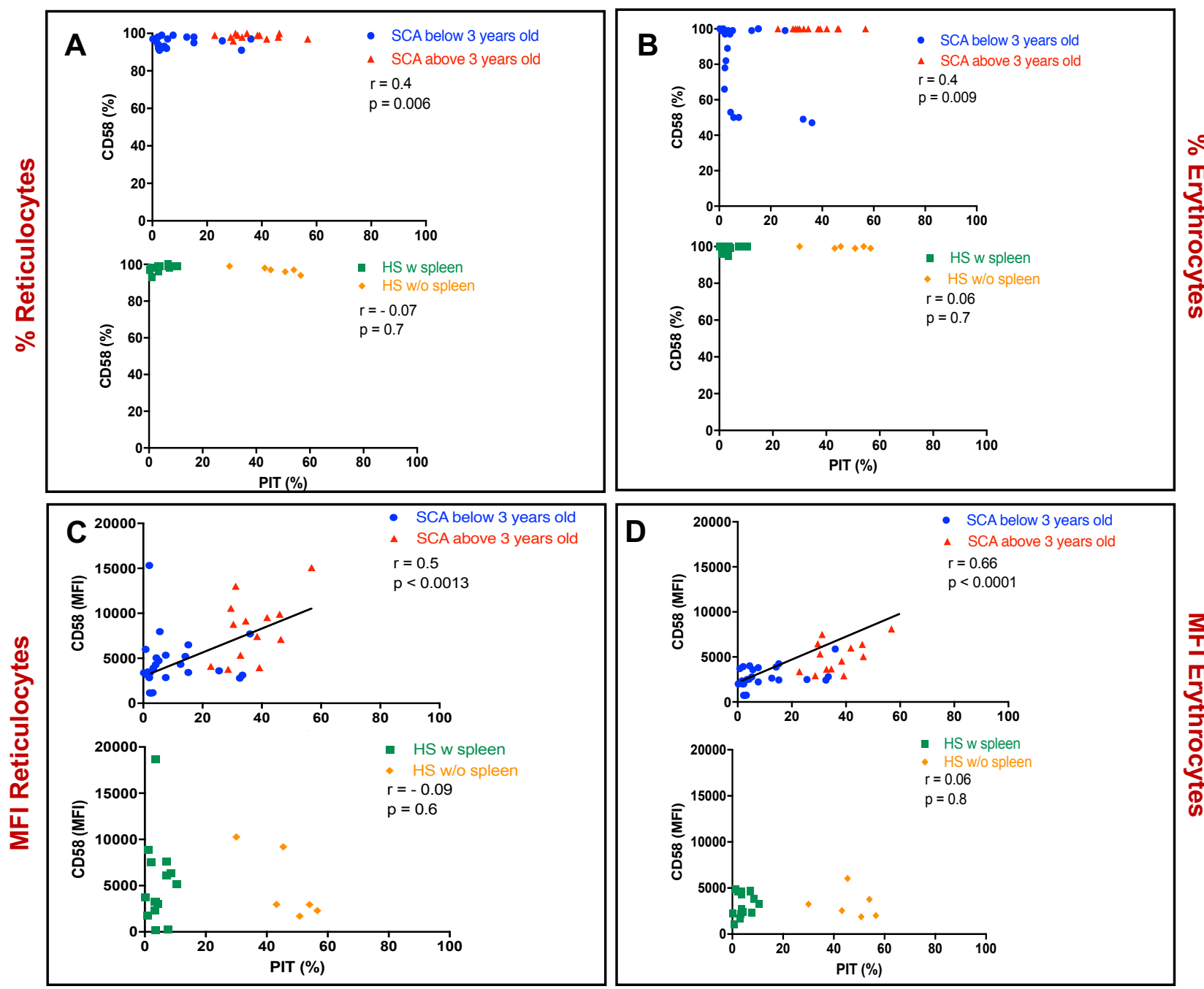

Figure 9. Correlation between CD58 and splenic function loss. (A-B) Frequency of reticulocytes (A) and erythrocytes (B) positive for CD58 in relation to the splenic function quantification (PIT) in SCA patients with preserved splenic function $(n=22)$ and and without $(n=$ 13) preserved splenic function (top) and in HS patients with $(n=15)$ and without $(n=6)$ spleen (bottom). (C-D) Correlation between CD58 MFI expression in reticulocytes (C) and erythrocytes (D) and PIT counting in SCA (top) and HS (bottom) patients. Spearman non-parametric linear correlation test.

Adhesion marker CD242 has shown to be more frequently expressed, in percentage (Figure 10A-B top), in reticulocytes and erythrocytes of SCA patients without preserved splenic function, although the MFI expression hasn't differed (Figure 10C-D top). On the other hand, only erythrocytes positive for CD99 and CD108 were more frequent in those SCA patients without spleen compared to SCA subjects with preserved splenic function (Figures 11-12B top). There was 
no correlation in the percentage or MFI expression of this markers between the

HS samples with and without the spleen (Figures 10-12, A-D bottom).
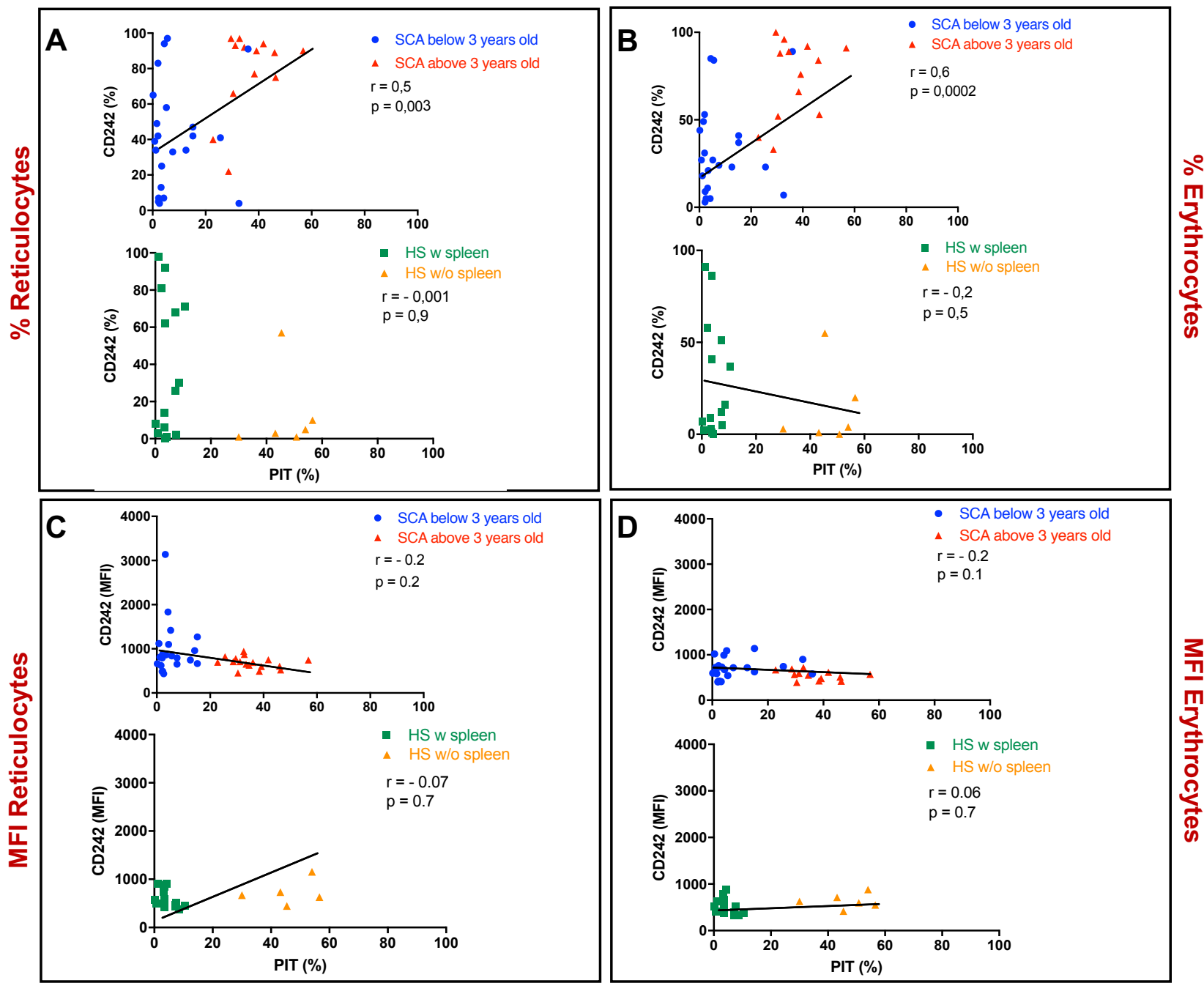

Figure 10. Correlation between CD242 and splenic function loss. (A-B) Frequency of reticulocytes (A) and erythrocytes (B) positive for CD242 in relation to the splenic function quantification (PIT) in SCA patients with preserved splenic function $(n=22)$ and and without $(n=$ 13) preserved splenic function (top) and in HS patients with $(n=15)$ and without $(n=6)$ spleen (bottom). (C-D) Correlation between CD242 MFI expression in reticulocytes (C) and erythrocytes (D) and PIT counting in SCA (top) and HS (bottom) patients. Spearman non-parametric linear correlation test. 

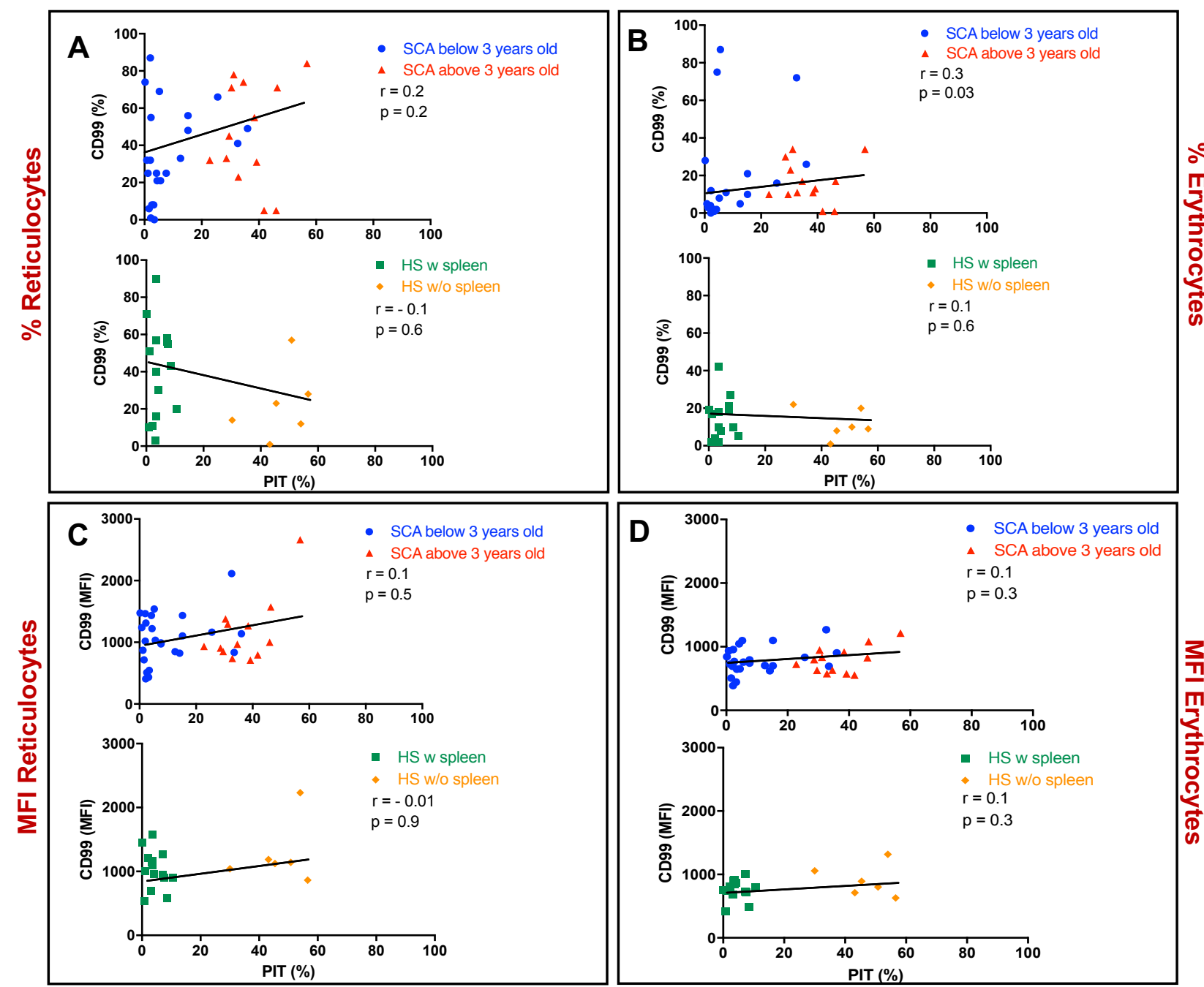

Figure 11. Correlation between CD99 and splenic function loss. (A-B) Frequency of reticulocytes (A) and erythrocytes (B) positive for CD99 in relation to the splenic function quantification (PIT) in SCA patients with preserved splenic function $(n=22)$ and and without $(n=$ 13) preserved splenic function (top) and in HS patients with $(n=15)$ and without $(n=6)$ spleen (bottom). (C-D) Correlation between CD99 MFI expression in reticulocytes (C) and erythrocytes (D) and PIT counting in SCA (top) and HS (bottom) patients. Spearman non-parametric linear correlation test. 

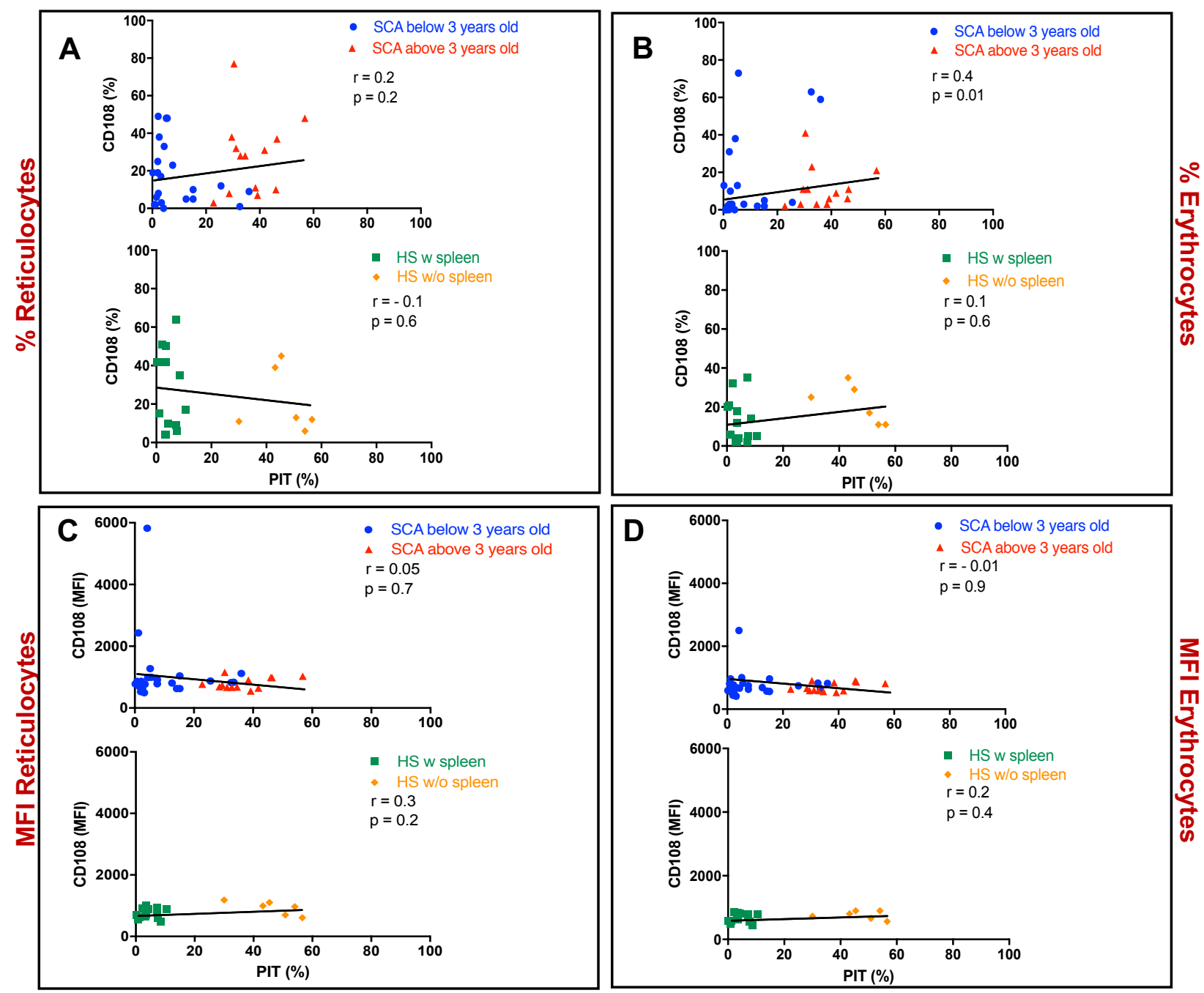

Figure 12. Correlation between CD108 and splenic function loss. (A-B) Frequency of reticulocytes $(A)$ and erythrocytes (B) positive for CD108 in relation to the splenic function quantification (PIT) in SCA patients with preserved splenic function $(n=22)$ and and without $(n=$ 13) preserved splenic function (top) and in HS patients with $(n=15)$ and without $(n=6)$ spleen (bottom). (C-D) Correlation between CD108 MFI expression in reticulocytes (C) and erythrocytes (D) and PIT counting in SCA (top) and HS (bottom) patients. Spearman non-parametric linear correlation test.

When the erythrocyte receptor for the extracellular matrix, CD44, was analyzed, the splenic function loss state presented increased MFI expression in reticulocytes and erythrocytes in SCA subjects with splenic function in relation to the group without preserved splenic function (Figure 13C-D top). RBCs frequency within the SCA and within the HS groups (Figure 13A-B), as well as the MFI expression within the HS groups (Figure 13C-D bottom) haven't shown significant difference. 

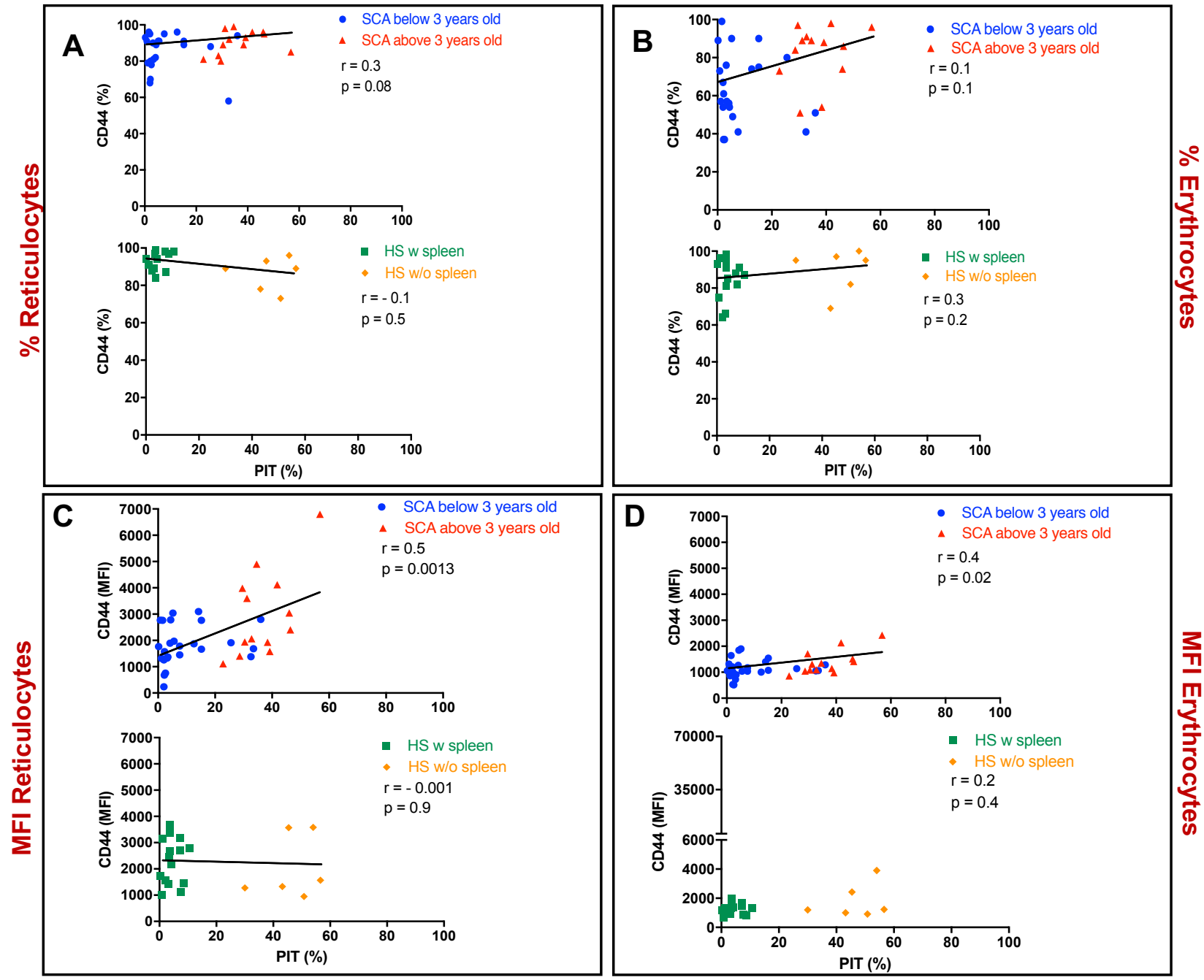

Figure 13. Correlation between CD44 and splenic function loss. (A-B) Frequency of reticulocytes $(A)$ and erythrocytes (B) positive for $C D 44$ in relation to the splenic function quantification (PIT) in SCA patients with preserved splenic function $(n=22)$ and and without $(n=$ 13) preserved splenic function (top) and in HS patients with $(n=15)$ and without $(n=6)$ spleen (bottom). (C-D) Correlation between CD44 MFI expression in reticulocytes (C) and erythrocytes (D) and PIT counting in SCA (top) and HS (bottom) patients. Spearman non-parametric linear correlation test.

For the CD47, CD36, CD49d and CD151 markers, no difference in frequency or in MFI expression was observed between groups with and without splenic function, both in SCA and HS (Figures 14-17, A-D). 

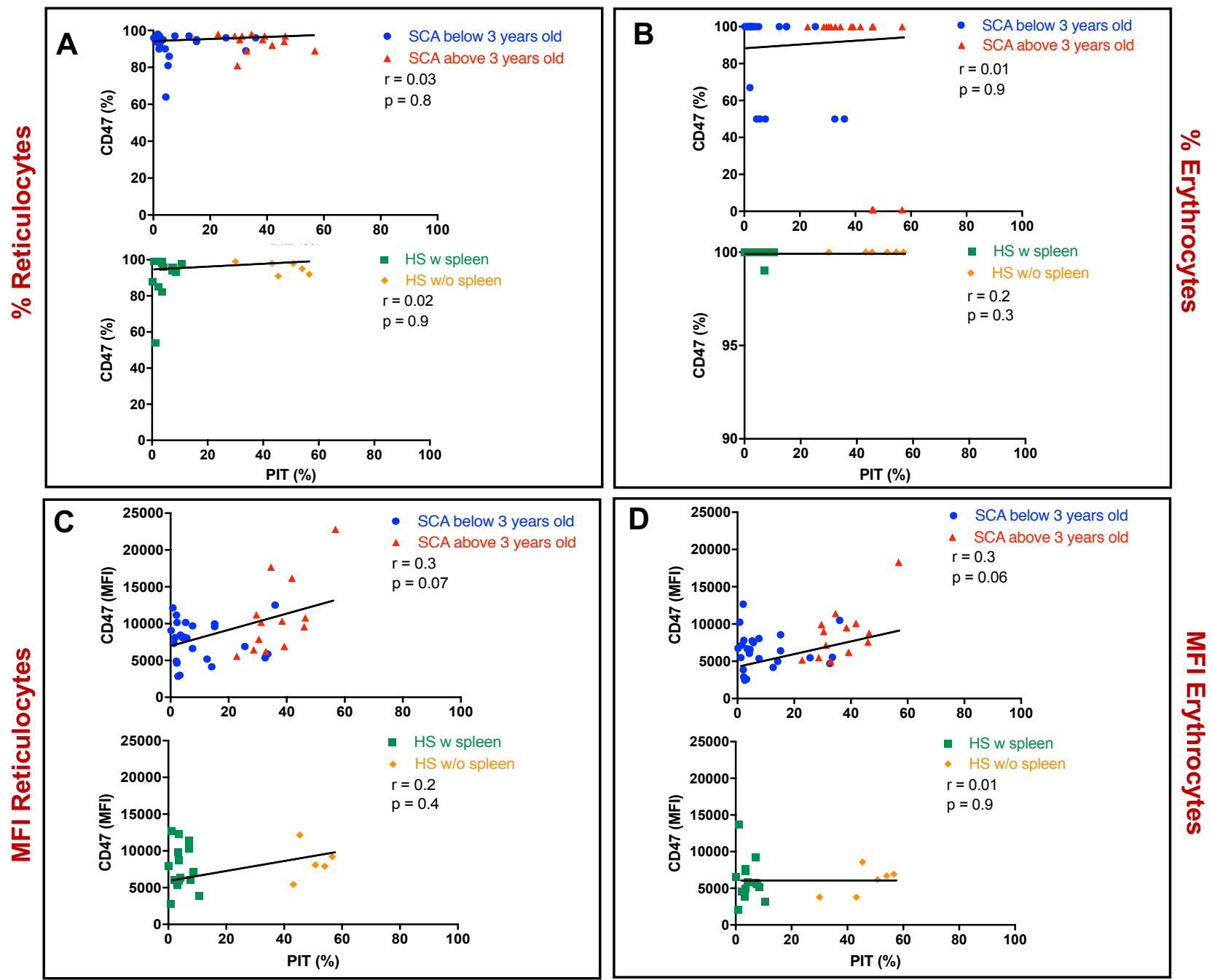

Figure 14. Correlation between CD47 and splenic function loss. (A-B) Frequency of reticulocytes $(A)$ and erythrocytes (B) positive for $C D 47$ in relation to the splenic function quantification (PIT) in SCA patients with preserved splenic function $(n=22)$ and and without $(n=$ 13) preserved splenic function (top) and in HS patients with $(n=15)$ and without $(n=6)$ spleen (bottom). (C-D) Correlation between CD47 MFI expression in reticulocytes (C) and erythrocytes (D) and PIT counting in SCA (top) and HS (bottom) patients. Spearman non-parametric linear correlation test 

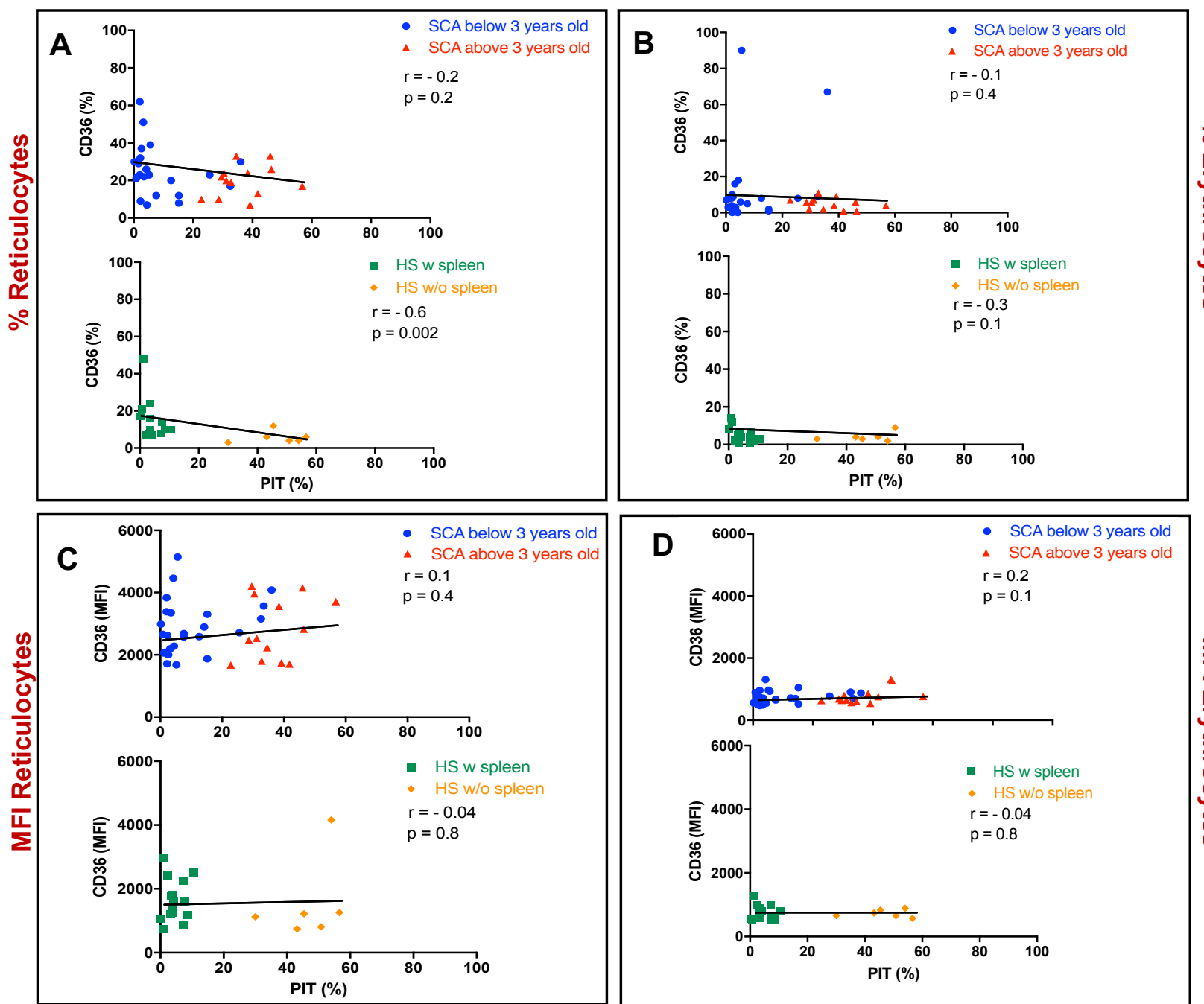

Figure 15. Correlation between CD36 and splenic function loss. (A-B) Frequency of reticulocytes (A) and erythrocytes (B) positive for CD36 in relation to the splenic function quantification (PIT) in SCA patients with preserved splenic function $(n=22)$ and and without $(n=$ 13) preserved splenic function (top) and in HS patients with $(n=15)$ and without $(n=6)$ spleen (bottom). (C-D) Correlation between CD36 MFI expression in reticulocytes (C) and erythrocytes (D) and PIT counting in SCA (top) and HS (bottom) patients. Spearman non-parametric linear correlation test. 

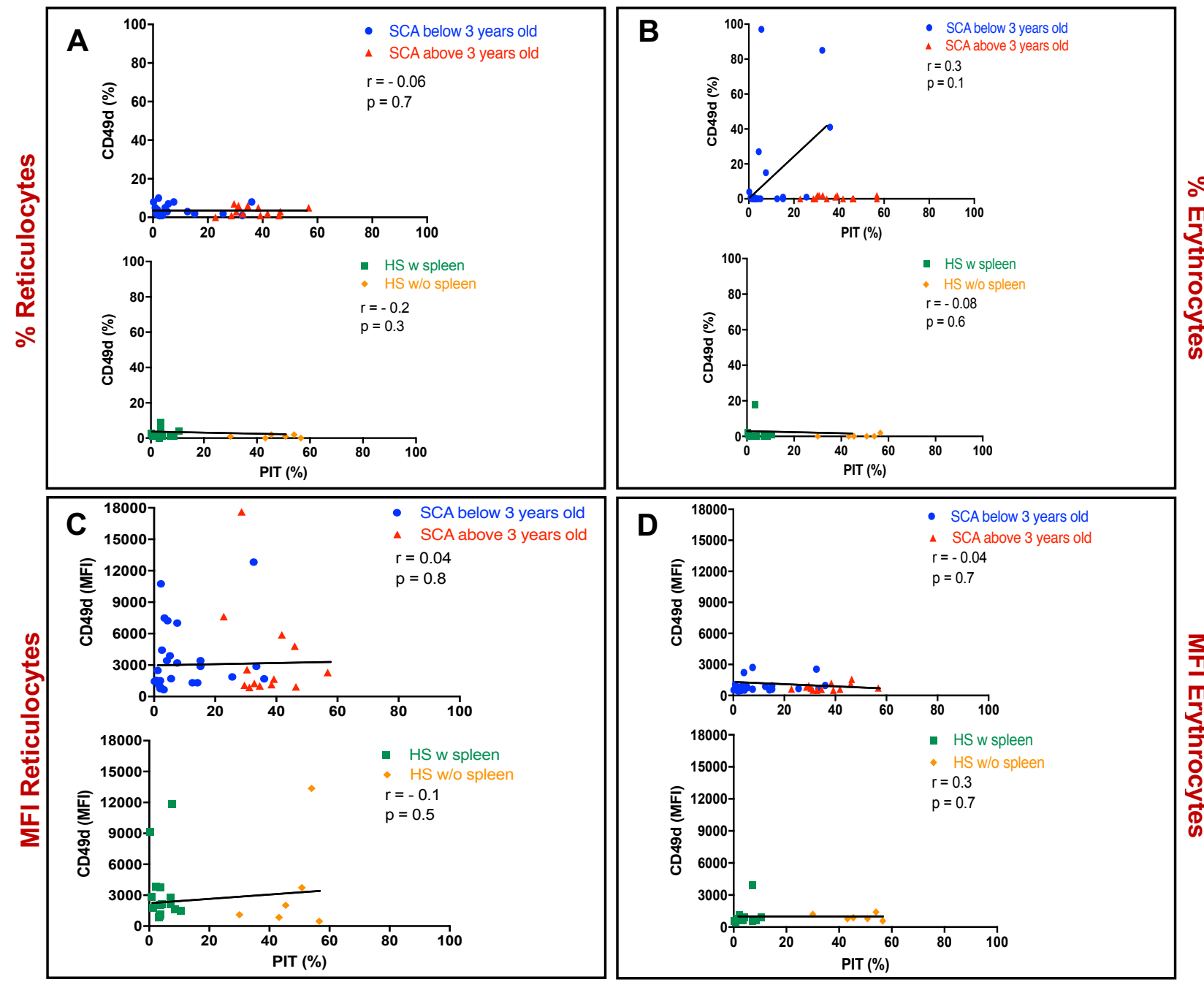

Figure 16. Correlation between CD49d and splenic function loss. (A-B) Frequency of reticulocytes $(A)$ and erythrocytes (B) positive for CD49d in relation to the splenic function quantification (PIT) in SCA patients with preserved splenic function $(n=22)$ and and without $(n=$ 13) preserved splenic function (top) and in HS patients with $(n=15)$ and without $(n=6)$ spleen (bottom). (C-D) Correlation between CD49d MFI expression in reticulocytes (C) and erythrocytes (D) and PIT counting in SCA (top) and HS (bottom) patients. Spearman non-parametric linear correlation test. 

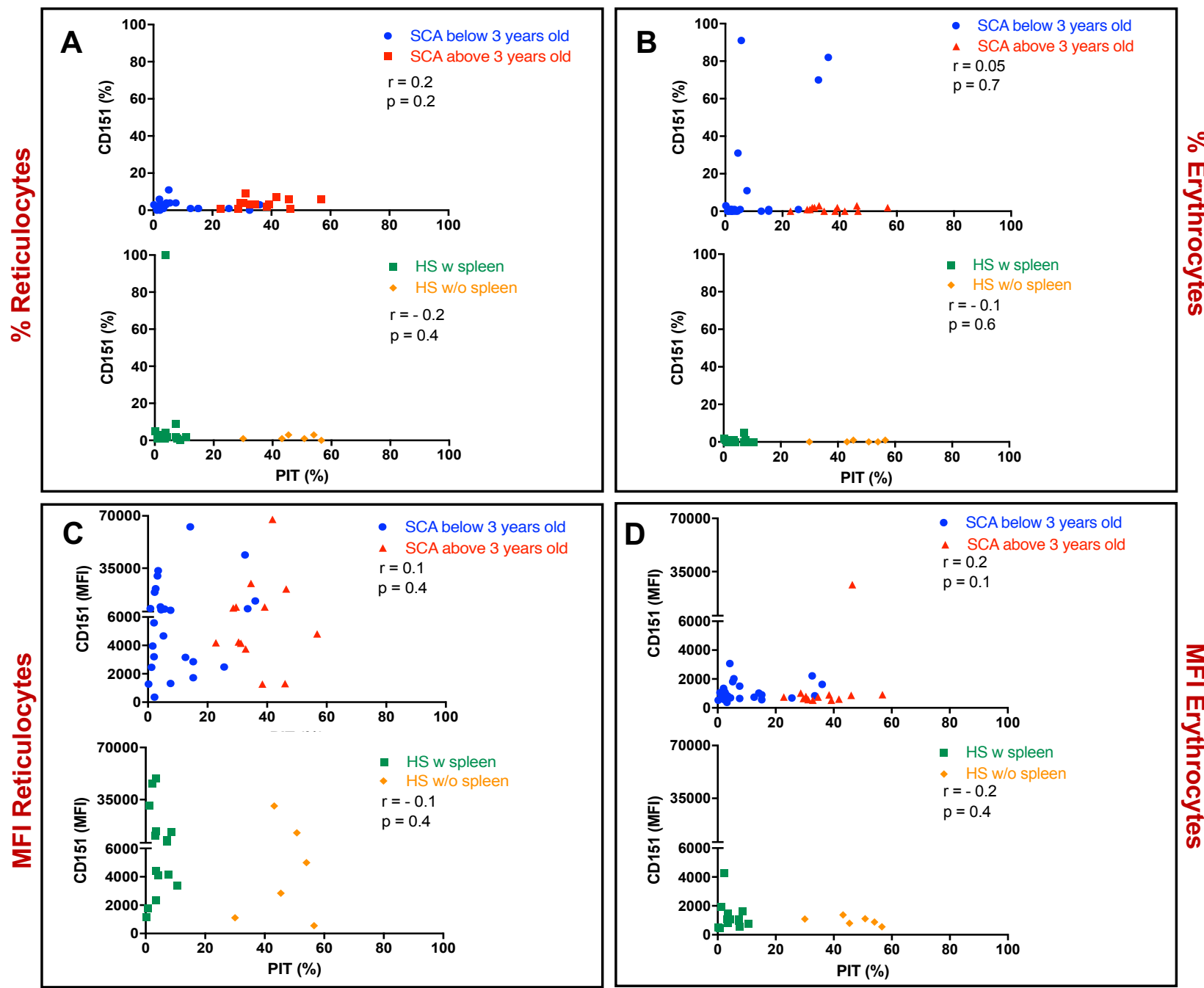

Figure 17. Correlation between CD151 and splenic function loss. (A-B) Frequency of reticulocytes (A) and erythrocytes (B) positive for CD151 in relation to the splenic function quantification (PIT) in SCA patients with preserved splenic function $(n=22)$ and and without $(n=$ 13) preserved splenic function (top) and in HS patients with $(n=15)$ and without $(n=6)$ spleen (bottom). (C-D) Correlation between CD151 MFI expression in reticulocytes (C) and erythrocytes (D) and PIT counting in SCA (top) and HS (bottom) patients. Spearman non-parametric linear correlation test. 


\subsubsection{Spleen absence/presence comparison}

In the first part of the cellular immunophenotypic analysis in relation to the splenic function loss, it was observed that there was a distribution pattern of pitted cell percentages, in which two main groups were detected: one group with PIT value lower than $20 \%$ and another one with PIT cell frequency higher than $20 \%$. Based on that, SCA patients were categorized again and considered in two groups with the following conformation:

- SCA group with preserved splenic function - patients who presented a PIT cell frequency lower than $20 \%$, without loss or with partial splenic function loss;

- SCA group without preserved splenic function - patients who presented $20 \%$ or more of circulating pitted cells, with total splenic function loss.

In this second part of the immunophenotypic analysis, we aimed to explore the reticulocytes and erythrocytes behavior in the presence or absence of splenic function.

Data obtained showed that the splenic function loss condition presented increased frequency and MFI expression of CD147, LuBCAM and CD58 on SCA reticulocytes and erythrocytes of subjects without splenic function in relation to those SCA samples with preserved splenic function (Figure 18A-D top). Besides that, CD242, CD99 and CD108 also stood out in frequency on both RBCs population surface (Figure 18A-B top). There was also an increased MFI expression of CD44+ reticulocytes (Figure 18C top).

On the other hand, reticulocytes LuBCAM+ and CD36+ were in lower frequency and showed decreased MFI expression in HS splenectomized patients compared to those ones with spleen (Figure 18A and C bottom), although the 
frequency of CD108 positive erythrocytes was higher in the first HS group mentioned (Figure 18B bottom).

In a nutshell, data obtained when comparing the spleen absence/presence in the two Hemolytic Anemias evaluated indicated that CD147, LuBCAM and CD58 are noteworthy adhesive markers in SCA pathophysiology. Regarding HS disease, there was a low adhesion marker expression pattern on both RBCs population in general. LuBCAM and CD36 were especially in significant lower frequency on reticulocytes surface of splenectomized individuals. 

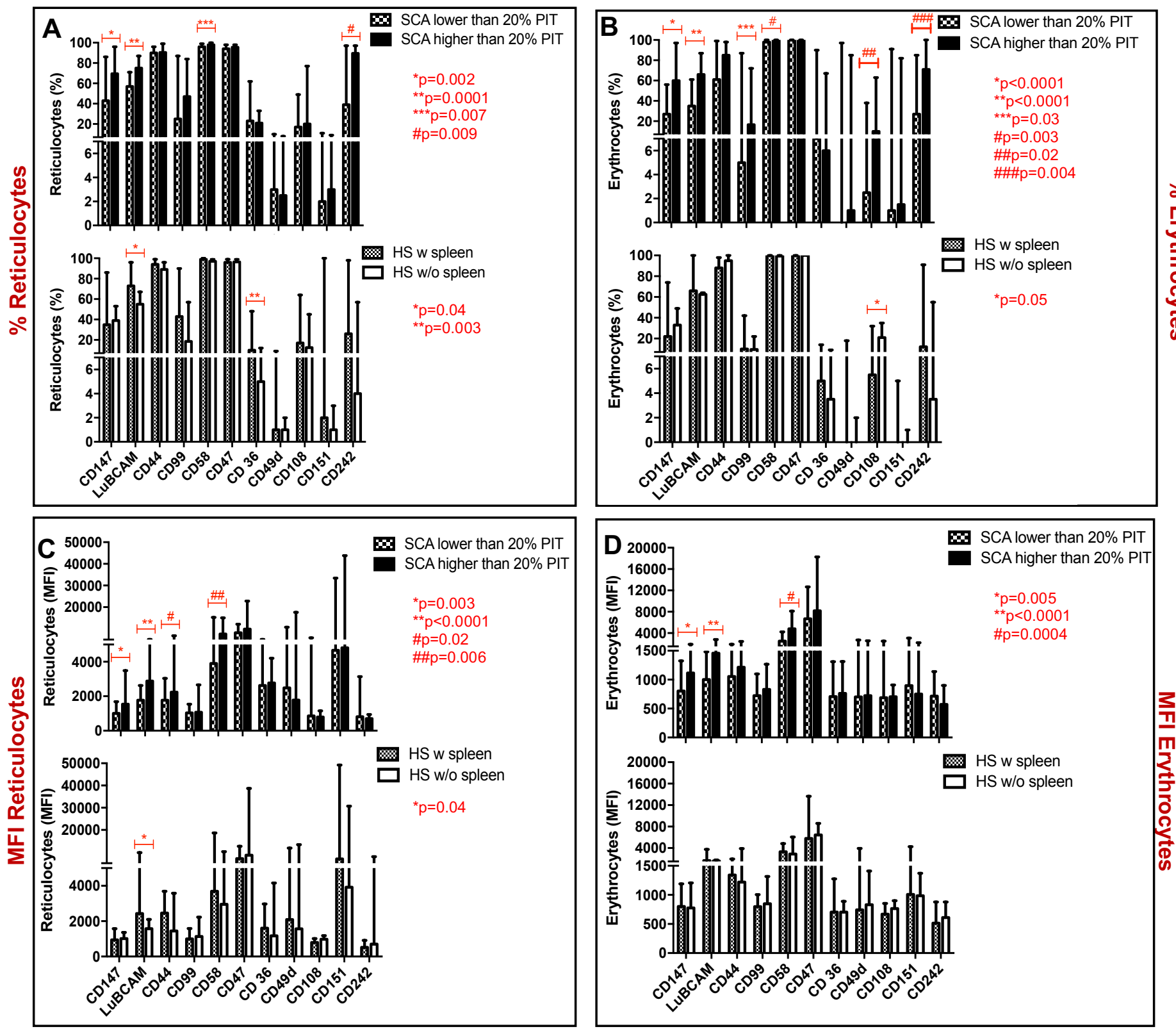

Figure 18. Distribution of circulating adhesive cells in the spleen absence/presence in SCA and HS patients. (A-B) Frequency of reticulocytes (A) and erythrocytes (B) positive for the adhesion markers tested between SCA samples from patients with (PIT less than $20 \%, n=19$ ) and without (PIT higher than 20\%, $\mathrm{n}=16$ ) preserved splenic function (top) and between HS samples from subjects with $(n=15)$ and without $(n=6)$ spleen (bottom). (C-D) MFI expression in reticulocytes (C) and erythrocytes (D) of SCA (top) and HS (bottom) blood from patients in the spleen absence/presence. Non-parametric Mann-Whitney test. Bars represent SEM. 


\subsubsection{Disease type comparison}

The next study approach took into account the type of disease, considering that, on one hand, the diseases evaluated in this study present different pathophysiology, but on the other hand, they share similarities as they are both Hereditary Hemolytic Anemias.

Analysis of the SCA and HS samples from patients with spleen has shown that reticulocytes and erythrocytes $\mathrm{LUBCAM}^{+}$were more frequent and showed higher MFI expression in HS samples with spleen than the SCA samples in the same condition (Figure 19A-D top). Likewise, reticulocytes and erythrocytes positive for CD44 and CD58 were presented in higher frequency in HS blood with spleen than in those SCA ones. Although, in the presence of the spleen, HS patients present a higher percentage of circulating cells positive for LuBCAM, CD44 and CD58 than SCA patients in the same condition, the frequency of these two adhesive populations of RBCs is high in patients with both diseases, of $40 \%$, or higher as shown in Figure 19A-B top. In contrast, CD36, CD242 and CD49d positive SCA reticulocytes were seen in higher percentages and with more surface epitopes expressed than in HS, in the presence of spleen (Figure 19A and $C$ top). These findings show that the pattern of adhesive phenotype of patients with spleen in these two hemolytic anemias is variable, which highlights the importance of the intrinsic pathophysiologies of each illness.

By analyzing the adhesive phenotypic pattern between SCA and HS patients without spleen, it has been found that after the splenic function loss, reticulocytes from SCA patients presented significant higher amount of positive circulating adhesive cells for the adhesion markers CD147, LuBCAM and CD36, as well as higher MFI expression of the same markers when compared to HS 
splenectomized patients (Figure 19A-C bottom). Still, SCA samples have also shown higher frequency of circulating reticulocytes for the markers CD99, CD49d and CD242 in relation to HS patients splenectomized (Figure 19A bottom). Focusing on the erythrocytes population in the SCA group without splenic function, we also detected a higher frequency of such cells positive for CD147 and CD242 (Figure 19B bottom), although the expression of the surface epitopes (MFI) did not differ in relation to the HS group in the same condition (Figure 19D bottom).

Together, the data have shown that, in the presence of spleen, HS patients presented higher frequency of adhesive circulating RBCs and higher intensity of expression of the corresponding molecules than the SCA subjects. However, once devoid of splenic function, SCA patients demonstrated greater adhesion molecules expression in RBCs, especially in reticulocytes, along with their increased MFI expression, in comparison to the HS group. 

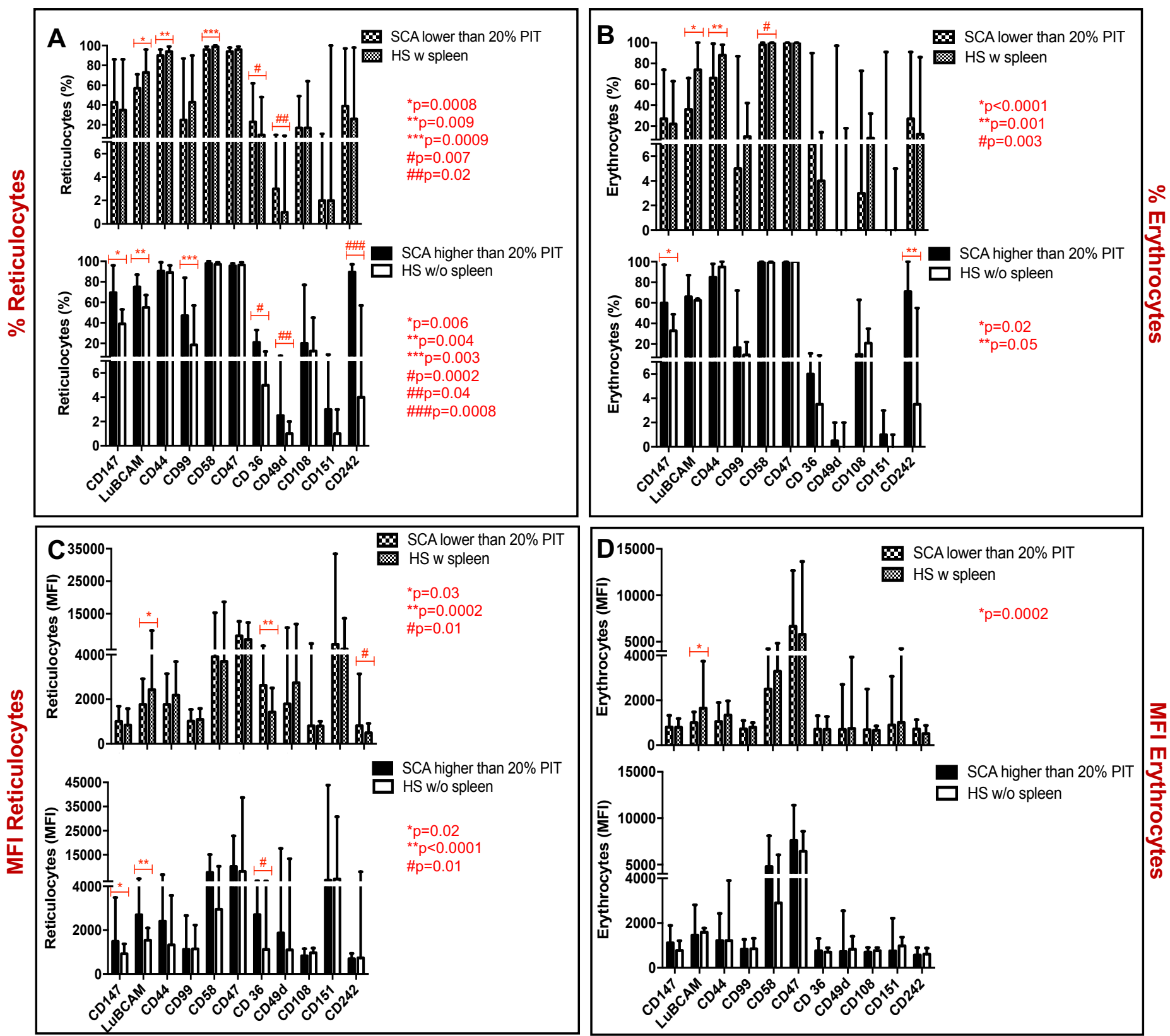

Figure 19. Distribution of adhesive cells according to the type of disease (SCA and HS). (A-B) Frequency of reticulocytes $(A)$ and erythrocytes $(B)$ positive for the adhesion markers tested between SCA (PIT less than $20 \%, n=19)$ and HS $(n=15)$ samples from subjects with spleen (top) and between SCA (PIT higher than 20\%, n = 16) and HS $(n=6)$ blood from patients without spleen (bottom). (C-D) MFI expression in reticulocytes (C) and erythrocytes (D) between SCA and HS blood samples from patients with spleen (top) and between SCA and HS patients without spleen (bottom). Non-parametric Mann-Whitney test. Bars represent SEM. 


\subsection{Cellular adhesion ability}

After the immunophenotypic profile analysis of reticulocytes and erythrocytes from patients affected by SCA and HS, we have undertaken the analysis of these cells effective adhesive potential. To do so, we have performed a cellular adhesion assay at an in vitro Platform that allows studies on cell-cell interaction (with prior cellular or non-cellular activation) or on cell-proteins of interest in adhesion, migration, transmigration, and other assays (Rainger et al., 1995, Gauthier et al., 2010, Munir H et al., 2015).

In the present work, the above-mentioned Platform has allowed us to evaluate the adhesion abilities of red cells to endothelial cells (HMEC-1 lineage) and to laminin, an abundant multiadhesive glycoprotein of the extracellular matrix essential in cellular adhesion processes and several others (Lodish et al., 2002).

Again, two types of comparison were established. In the first one, we aimed to evaluate possible differences within the two diseases studied under the spleen presence/absence condition. The second analysis compared the cellular adhesive performance between the diseases under the same condition, that is, both with preserved splenic function or both without it.

\subsubsection{Spleen absence/presence comparison}

When SCA samples without preserved splenic function were compared to SCA with it, the first group's RBCs presented significant increase in adhesiveness to laminin in all the six flow speeds applied (Figure 20A). However, not only the overall adhesive ability to HMEC-1 was considerably inferior than the one detected against laminin, but also there was no difference between the RBCs quantification of SCA subjects before and after the splenic function loss (Figure 
B). But then, when quantified RBCs that were adhered to HMEC-1 were subdivided into reticulocytes and erythrocytes, significant higher adhesiveness was observed in SCA reticulocytes from individuals without preserved splenic function compared to those with spleen at the rate of $1 \mathrm{dyne} / \mathrm{cm}^{2}$, which mimics the closest blood flow speed in vivo (Figure 20C). Noteworthy, of all the RBCs adhered to HMEC-1 lineage, most of them were composed of erythrocytes, but no difference was observed regarding the erythrocytes adhesive ability to HMEC-

1 (Figure 20D). Anyhow, reticulocytes and erythrocytes were resistant to washoff by increasing shear stress and remained adhered until the last flow rate applied.

Regarding the spleen absence/presence analysis on the HS groups, there was no significant difference between groups, although the adhesive potential of HS reticulocytes and erythrocytes has also shown resistance to wash-off at an increasing shear stress in general, and, although adhesion to laminin has been visually higher in the HS splenectomized group compared to the one with spleen (Figure 21A-B). Worthy of comment, the high variation of the standard deviation bars indicates the need of increasing the number of samples evaluated $(n=4)$, in order to improve the robustness of the analysis.

Nevertheless, observing the subpopulations of HMEC-1 quantified, the adhesive reticulocytes from splenectomized HS patients were detected in higher amount than the samples of HS subjects with spleen at the rate of $1 \mathrm{dyne} / \mathrm{cm}^{2}$ again (Figure 21C). Still, of all the RBCs adhered to HMEC-1 lineage, most of them were composed of erythrocytes again but the small amount of reticulocytes that adhered couldn't resist the increasing shear stress washing imposed, unlike the erythrocytes (Figure 21C-D). 
In a summary, in the spleen absence condition, SCA RBCs exhibited higher adhesive ability to laminin rather the corresponding group with preserved splenic function. Moreover, it should be also pointed out the reticulocyte higher adhesive ability against HMEC-1 in both Hemolytic Anemias at a shear stress flow rate similar to the blood flow in vivo. 


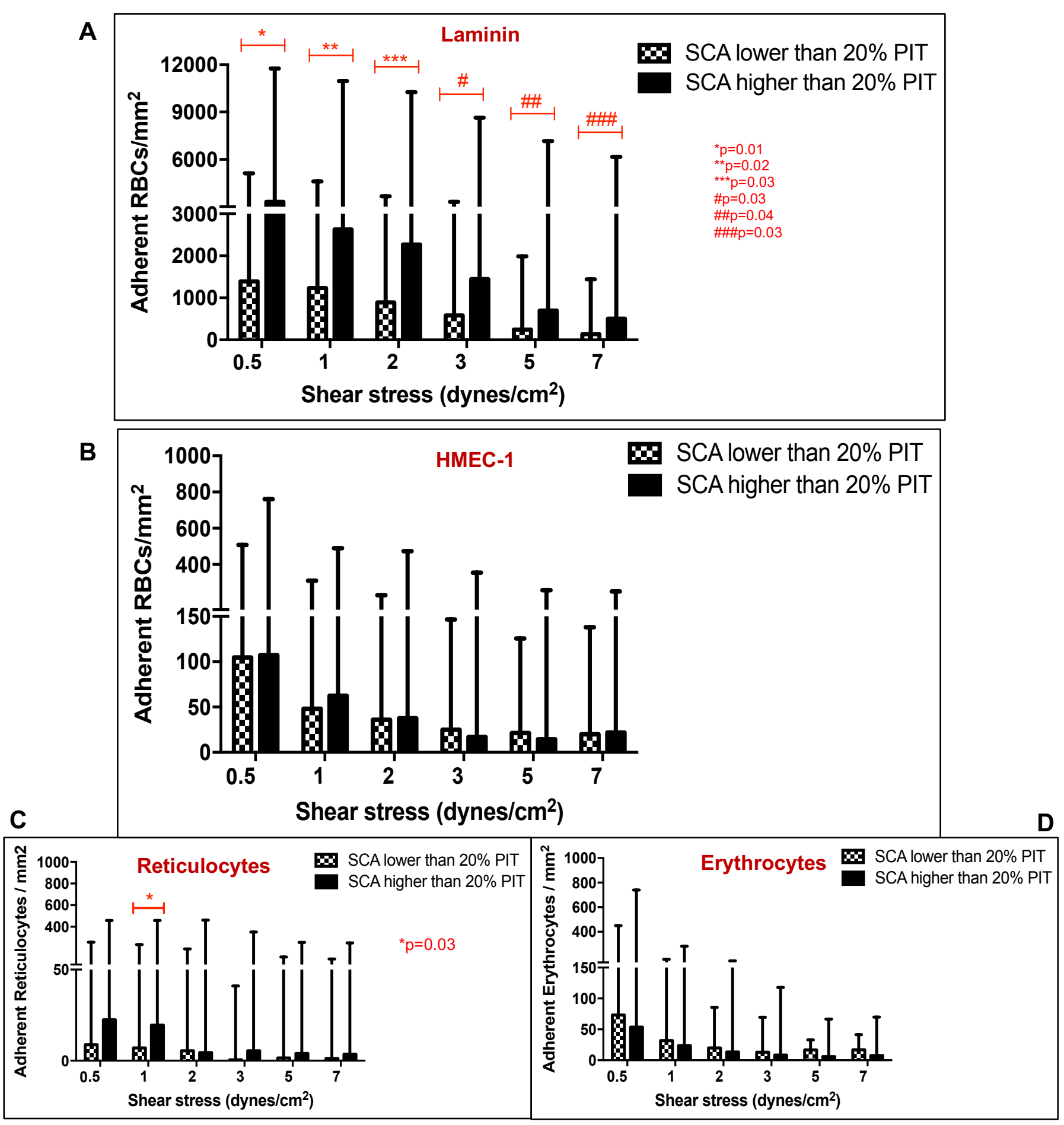

Figure 20. RBCs adhesive ability under flow conditions with increasing shear stress in the spleen absence/presence in SCA. (A) Number of SCA RBCs with splenic function $(n=16)$ remaining adherent to laminin versus SCA RBCs without splenic function $(n=12)$ in biochips after inflow at $0.5 \mathrm{dyne} / \mathrm{cm}^{2}$ and washout at increasing shear stress. (B) Number of SCA RBCs with spleen adherent to HMEC-1 versus SCA RBCs without spleen after inflow at different wall shear stresses. Reticulocyte (C) and erythrocyte (D) adhesiveness subquantification against HMEC-1 under the same conditions mentioned above. Non-parametric Mann-Whitney test. Bars represent SEM. 


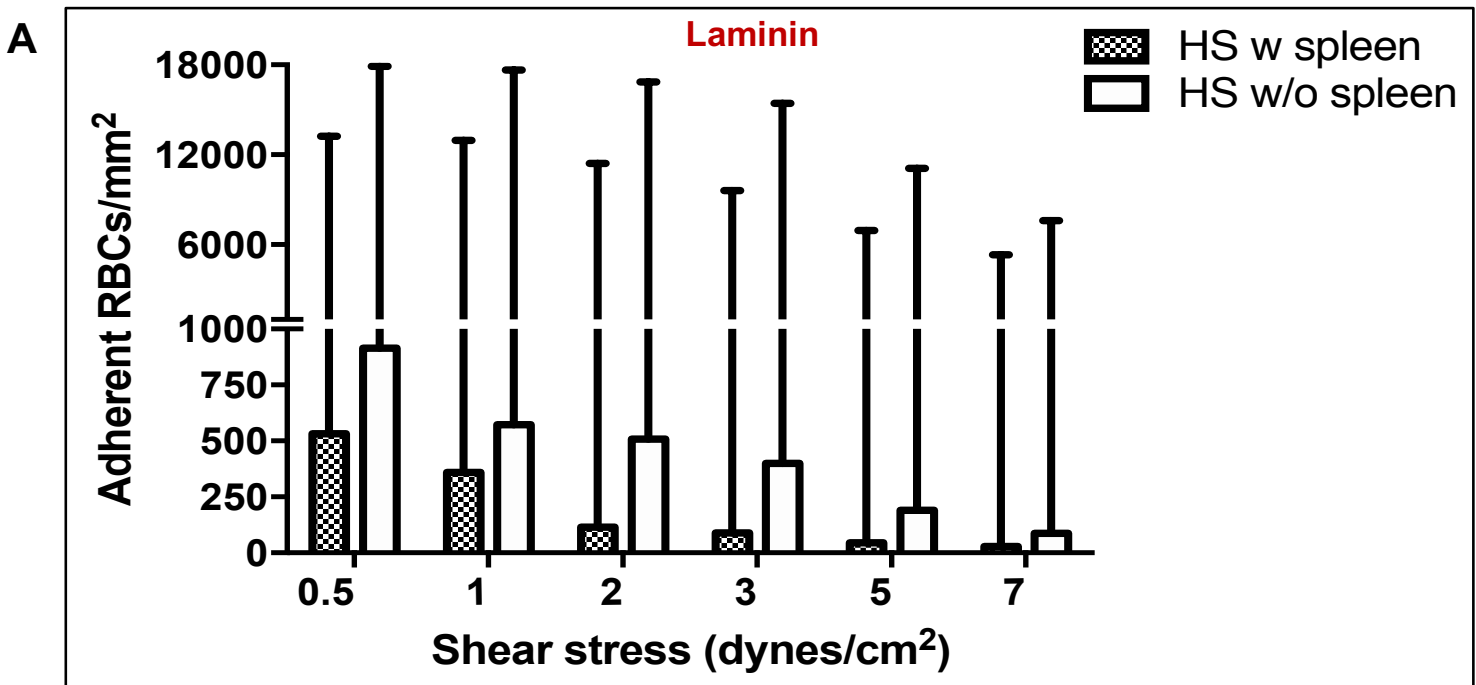

B
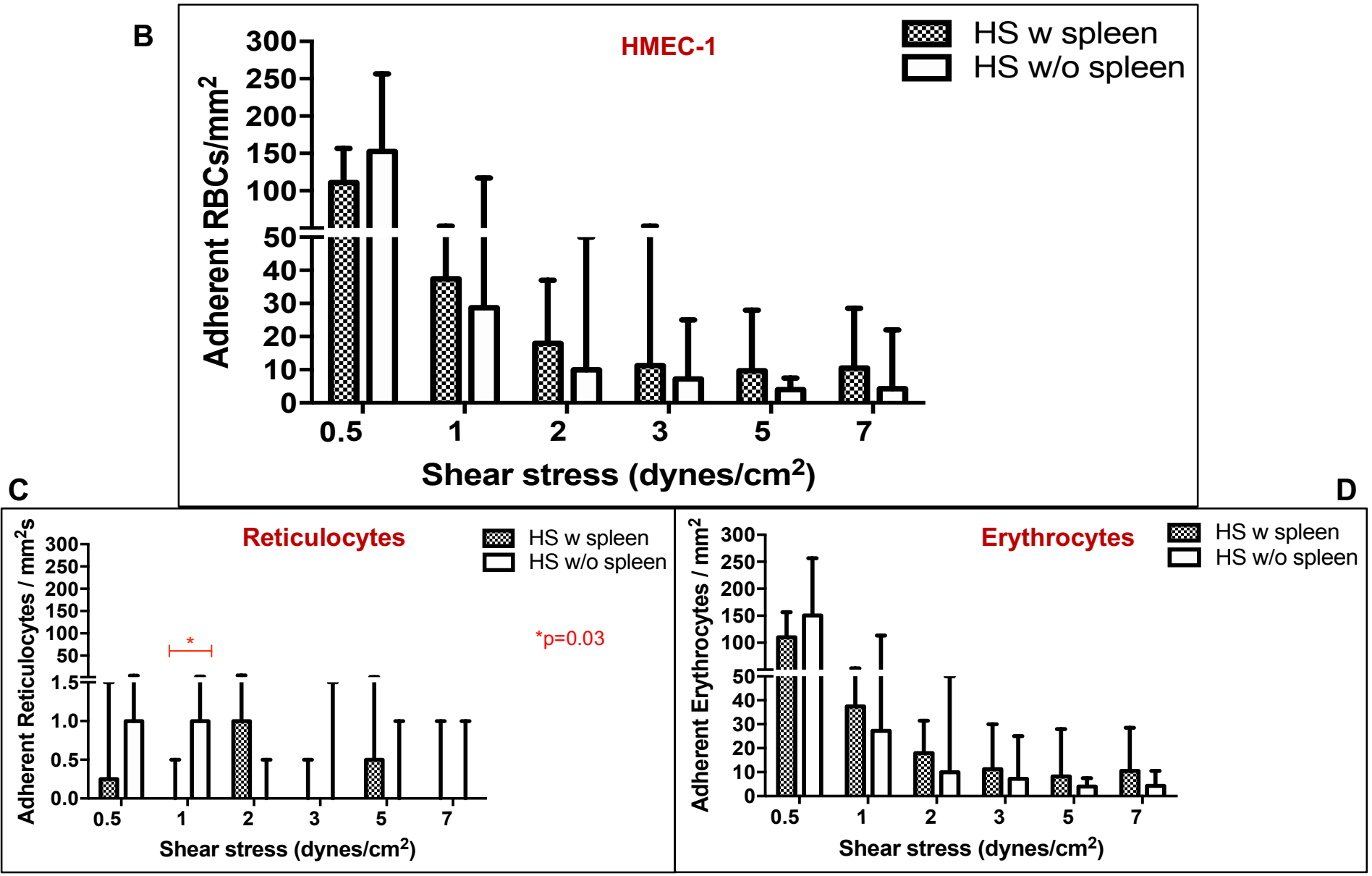

Figure 21. RBCs adhesive ability under flow conditions with increasing shear stress in the spleen absence/presence in HS. (A) Number of HS RBCs with splenic function $(n=4)$ remaining adherent to laminin versus HS RBCs without splenic function $(n=4)$ in biochips after inflow at 0.5 dyne $/ \mathrm{cm}^{2}$ and washout at increasing shear stress. (B) Number of HS RBCs with spleen adherent to HMEC-1 versus HS RBCs without spleen after inflow at different wall shear stresses. Reticulocyte (C) and erythrocyte (D) adhesiveness subquantification against HMEC-1 under the same conditions mentioned above. Non-parametric Mann-Whitney test. Bars represent SEM. 


\subsubsection{Disease type comparison}

Data obtained from the comparison of the disease type showed that once in the condition of spleen presence, SCA and HS samples did not differ in adhesiveness to laminin and to HMEC-1 (Figure 22A-B). However, the quantified reticulocyte subpopulation that adhered to HMEC-1 presented significant higher adhesive potencial in the SCA samples than in the corresponding HS group at low shear stress rates $\left(0.5\right.$ and 1 dynes $\left./ \mathrm{cm}^{2}\right)$ (Figure $22 \mathrm{C}$ ).

Lastly, after splenic function loss, SCA and HS cells showed no significant difference in adhesiveness against laminin (Figure 23A), although SCA samples tended visually to show a more adhesive pattern than HS cells. This event may have happened due to the high variation observed by the standard deviation bars which makes it important to reiterate the need of increasing the number of HS samples $(n=4)$ evaluated in order to obtain more representative outcome.

Focusing on the analysis of RBCs to HMEC-1 adhesive ability, the overall quantification showed higher adhesiveness of RBCs only at 5 dynes $/ \mathrm{cm}^{2}$, a high flow rate. But then, the observation of reticulocytes and erythrocytes subquantification revealed that SCA reticulocytes were more adhesive to HMEC1 in almost all the shear stress flow rates applied $\left(0.5,2,3,5\right.$ and 7 dynes $\left./ \mathrm{cm}^{2}\right)$, unlike the lack of singnificant difference in the adhesive potential between the groups' erythrocytes against HMEC-1 (Figure 23D).

Together, these findings show that reticulocytes may present a higher adhesive potential against endothelial cells in SCA individuals than in HS patients, in both conditions, either with or without the spleen. Data also showed that, in general, RBCs had a greater adhesive binding to laminin than to HMEC1 lineage. 


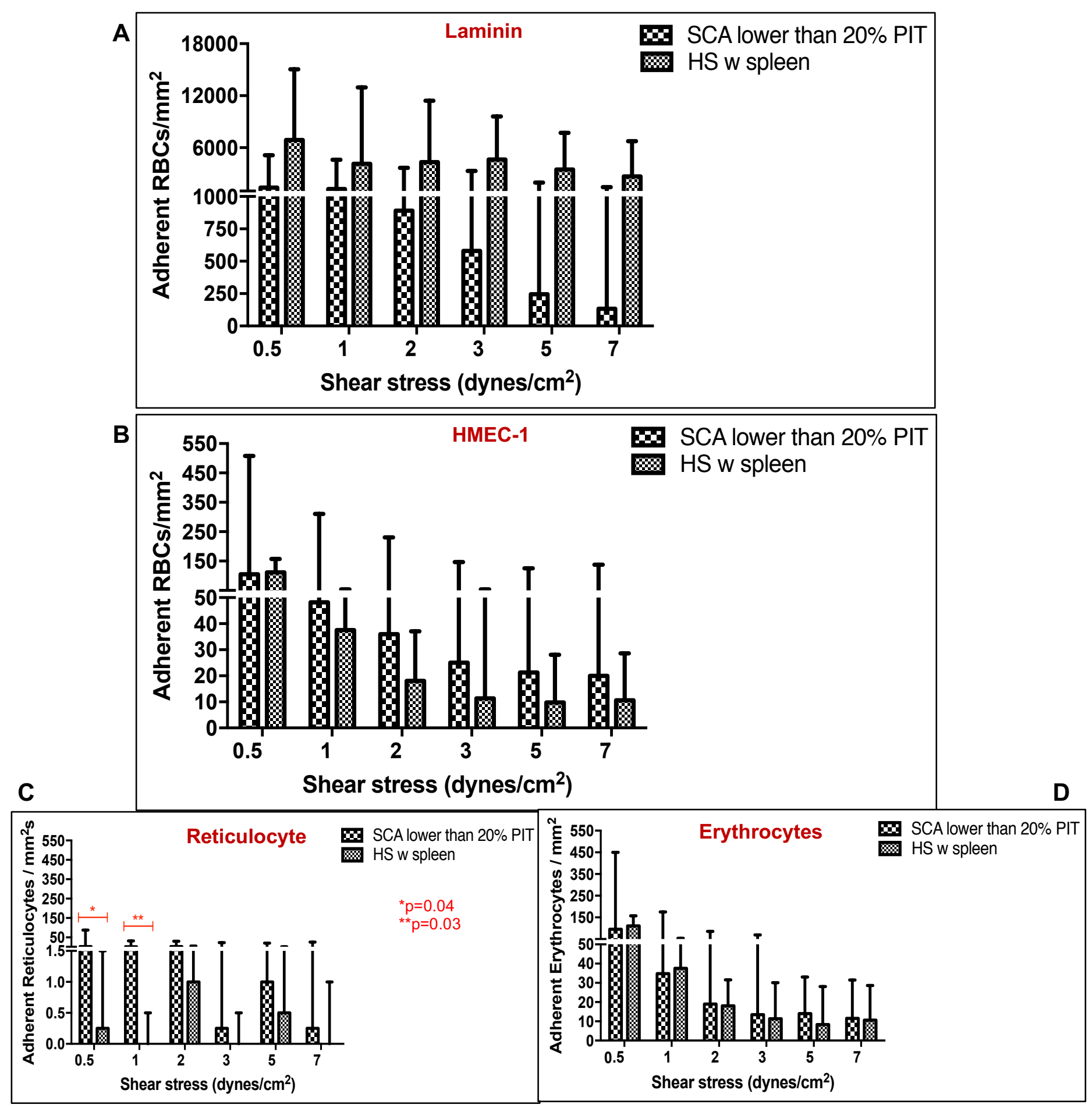

Figure 22. RBCs adhesive ability under flow conditions with increasing shear stress, according to the type of disease (SCA and HS with spleen). (A) Number of SCA RBCs ( $n=$ 16) remaining adherent to laminin versus HS RBCs $(n=4)$, with splenic function, in biochips after inflow at $0.5 \mathrm{dyne} / \mathrm{cm}^{2}$ and washout at increasing shear stress. (B) Number of SCA RBCs adherent to HMEC-1 versus HS RBCs, with spleen, after inflow at different wall shear stresses. Reticulocyte (C) and erythrocyte (D) adhesiveness subquantification against HMEC-1 under the same conditions mentioned above. Non-parametric Mann-Whitney test. Bars represent SEM. 


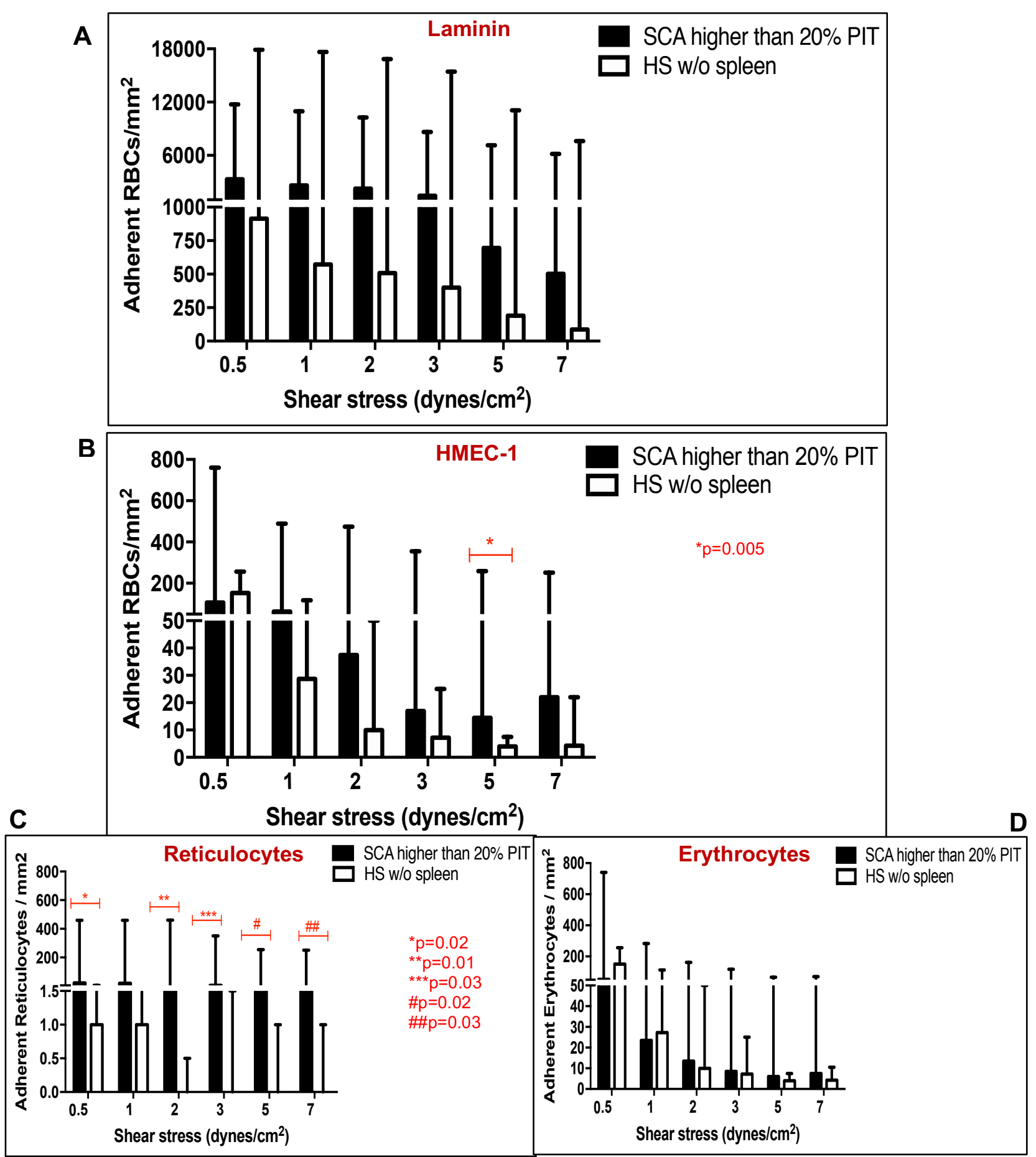

Figure 23. RBCs adhesive ability under flow conditions with increasing shear stress, according to the type of disease (SCA and HS without spleen). (A) Number of SCA RBCs ( $=12$ ) remaining adherent to laminin versus HS RBCs $(n=4)$, without splenic function, in biochips after inflow at $0.5 \mathrm{dyne} / \mathrm{cm}^{2}$ and washout at increasing shear stress. (B) Number of SCA RBCs adherent to HMEC-1 versus HS RBCs, without spleen, after inflow at different wall shear stresses. Reticulocyte (C) and erythrocyte (D) adhesiveness subquantification against HMEC-1 under the same conditions mentioned above. Non-parametric Mann-Whitney test. Bars represent SEM. 
CONCLUSION 


\section{CONCLUSION}

- Splenic function quantification presented a slight decrease with aging in the first months of life (6 to 29 months). However, from 3 years of life on splenic function significantly decreased with aging in patients with SCA;

- Immunophenotypic findings showed that, in general, the more advanced the splenic function loss (higher PIT count) was, the more frequent in circulation RBCs positive for the erythrocytes markers CD147, LuBCAM and CD58 were in SCA samples.

- Spleen absense played a notable role in the increase of reticulocytes and erythrocytes adhesion expression in SCA, although it led to decrease of cell adhesion expression pattern in splenectomized HS patients. CD147, LuBCAM and CD58 positive reticulocytes and erythrocytes adhesion expression stood out in SCA patients without splenic function.

- Regarding the disease type comparison, HS patients with spleen presented higher frequency of cell adhesion expression. However, SCA samples without splenic function showed remarkable greater cell adhesion expression in comparison to HS splenectomized individuals. LuBCAM, CD44 and CD58 positive reticulocytes and erythrocytes adhesion expression was noteworthy in HS patients with splenic function, although CD36, CD242 and CD49d positive reticulocytes expression was higher in SCA with and without spleen.

- Focusing on the adhesion ability assay, in the spleen absence, SCA RBCs exhibited higher adhesive ability to laminin than the SCA RBCs with preserved splenic function. Reticulocytes of patients without spleen presented higher adhesiveness against HMEC-1 at low shear stress $\left(1 \mathrm{dyne} / \mathrm{cm}^{2}\right)$ in both 
Hemolytic Anemias, considering the due proportions of being in much larger numbers in SCA patients.

- Furthermore, disease type comparison in the adhesion assay detected that reticulocytes presented a higher adhesive potential against endothelial cells in SCA individuals than in HS patients, either with or without spleen. Data also showed that, RBCs had a greater adhesive binding to laminin than to HMEC-1.

Together, our results indicate that although both diseases belong to the to Hemolytic Anemias group that encompasses RBCs intrinsic defects, SCA and HS distinct pathophysiologies and clinical evolution lead to different immunophenotypic patterns of cell adhesion expression. In SCA, the absence of splenic function may have a direct relation with the increase of SCA RBCs proadhesive phenotype and adhesiveness, which brings serious clinical consequences to the patients, whereas in HS without spleen, in general, cellular adhesion events are minimized, although they still present adhesive circulating reticulocytes and erythrocytes after splenectomy. 


\section{BIBLIOGRAPHIC REFERENCES}

ALBERTS, B. et al. Biologia Molecular da Célula. 5ed. Porto Alegre (RS): Artmed Press; 2010. 1601p.

AN, X., MOHANDAS, N. Disorders of red cell membrane. Br J Haematol, v.141, n.3, p.367-75. 2008.

BRASIL. Ministério da Saúde. Protocolo Clínico e Diretrizes Terapêuticas para a Doença Falciforme. Brasília (DF): Comissão Nacional de Incorporaçao de Tecnologias no SUS. 2016. 29p.

BROUSSE, V. et al. The spleen and sickle cell disease: the sick(led) spleen. $\mathrm{Br}$ J Haematol, v.166, n.2, p.165-76. 2014.

BUNN, H.F. The triumph of good over evil: protection by the sickle gene against malaria. Blood, v.121, n.1, p.20-5. 2013.

CHASIS, J.A. Erythroblastic islands: specialized microenvironmental niches for erythropoiesis. Current Opinion in Hematology, v.13, p.137-41. 2006.

CHIANG, E.Y., FRENETTE, P.S. Sickle cell vaso-occlusion. Hematol Oncol Clin North Am, v.19, n.5, p.771-84. 2005.

COOKE, B.M. et al. A simplified method for culture of endothelial cells and analysis of adhesion of blood cells under conditions of flow. Microvascular Research, v.45, p.33-45. 1993.

CORAZZA, G.R. et al. Howell-Jolly body counting as a measure of splenic function. A reassessment. Clin Lab Haematol, v.12, n.3, p.269-75. 1990.

COVAS, D.T., ZAGO, M.A. Splenic function in chronic myelogenous leukemia. Eur J Haematol, v.39, n.5, p.434-9. 1987.

COVAS, D.T. Avaliação da função esplênica em leucemias crônicas e mielofibrose. 1985. 109p. Dissertação (Mestrado) - Faculdade de Medicina de Ribeirão Preto. Universidade São Paulo, São Paulo. 
DHALIWAL, G., CORNETT, P.A., TIERNEY, L.M.Jr. Hemolytic anemia. Am Fam Physician, v.1, n.69, p.2599-606. 2004.

DARGHOUTH, D. et al. Pathophysiology of sickle cell disease is mirrored by the red blood cell metabolome. Blood, v.117, n.6, p.57-66. 2011.

DE BACK, D.Z. Of macrophages and red blood cells; a complex love story. Frontiers in Physiology, v.5. 2014.

EL NEMER, W. et al. Role of Lu/BCAM in abnormal adhesion of sickle red blood cells to vascular endothelium. Transfus Clin Biol, v.15, p.29-33. 2008.

EL NEMER, W. et al. Role of Lu/BCAM glycoproteins in red cells diseases. Transfus Clin Biol, v.15, p.143-7. 2010.

EMBURY, S.H. et al. Sickle Cell Disease: Scientific Principles and Clinical Practice. 1ed. New York (NY): Ravin Press Ltd.; 1994. 902p.

GALLAGHER, P.G. Abnormalities of the erythrocyte membrane. Pediatr Clin North Am, v.60, n.6, p.1349-62. 2013.

GAUTHIER, E. et al. Role of the interaction between Lu/BCAM and the spectrinbased membrane skeleton in the increased adhesion of hereditary spherocytosis red cells to laminin. Br J Haematol, v.148, n.3, p.456-65. 2010.

GRANJO, E. et al. Esferocitose hereditária - Prevalência dos défices proteicos da membrana do eritrócito. Rev. Acta médica portuguesa, v.16, p.65-9. 2003.

LEWIS, S. M., BAIN, B. J., BATES, I. Dacie and Lewis Practical Haematology. $10^{\mathrm{a}}$ ed. Philadelphia (PA): Churchill Livingstone Elsevier; 2006. 722p.

LIU, S. et al. Erythropoiesis in the Absence of Adult Hemoglobin. Molecular and Cellular Biology, v.33, n.11, p.2241-51. 2013.

LODISH, H. et al. Biologia Celular e Molecular. 4ed. Rio de Janeiro (RJ): Revinter Bookstore and Press Ltd.; 2002. 1084p. 
LOGGETTO, S.R. Sickle cell anemia: clinical diversity and beta S-globin haplotypes. Rev Bras Hematol Hemoter, v.35, n.3, p.153-62. 2013.

MAIER-REDELSPERGER, M. et al. Variation in fetal hemoglobin parameters and predicted hemoglobin $S$ polymerization in sickle cell children in the first two years of life: Parisian Prospective Study on Sickle Cell Disease. Blood, v.84, n.9, p.3182-8. 1994.

MAIER-REDELSPERGER, M. et al. Fetal hemoglobin and F-cell responses to long-term hydroxyurea treatment in young sickle cellpatients. The French Study Group on Sickle Cell Disease. Blood, v.91, n.12, p.4472-9. 1998.

MANWANI, D. and BIEKER, J.J. The erythroblastic island. Curr. Top. Dev. Biol, v.82, p.23-53. 2008.

MODELL, B. and DARLISON, M. Global epidemiology of haemoglobin disorders and derived service indicators. Bulletin of the World Health Organization, v.86, p.480-87. 2008.

MOUSINHO-RIBEIRO, R.C. et al. The importance of the evaluation of fetal hemoglobin in the clinical assessment of sickle cell disease. Rev. bras. hematol. Hemoter, v.30, n.2, p.136-41.

MUNIR, H. et al. Analyzing the effects of stromal cells on the recruitment of leukocytes from flow. J Vis Exp, v.95, e.52480. 2015.

NATHAN, D.G., GUNN, R.B. Thalassemia: the consequences of unbalanced hemoglobin synthesis. Am J Med, v.41, n.5, p.815-30. 1966.

NAOUM, P.C. e NAOUM, F.A. Doença das Células Falciformes. 1ed. São Paulo (SP): Sarvier Press; 2004. 224p.

NOURAIE, M. et al. The relationship between the severity of hemolysis, clinical manifestations and risk of death in 415 patients with sickle cell anemia in the US and Europe. Haematologica, v.98, n.3, p.464-72. 2013.

PEARSON, H.A., et al. Developmental pattern of splenic dysfunction in sikle cell disorders. Pediatrics, v.76, n.3, p.392-7. 1985. 
RAINGER, G.E. et al. Adhesion of flowing neutrophils to cultured endothelial cells after hypoxia and reoxygenation in vitro. American Journal of Physiology, v.269, n.4, p.1398-406. 1995.

REES, D.C., WILLIAMS, T.N., GLADWIN, M.T. Sickle-cell disease. Lancet, v.376, n.9757, p.2018-31. 2010.

ROGERS, Z.R. et al. Biomarkers of splenic function in infants with sickle cell anemia: baseline data from the BABY HUG trial. Blood. 2011.

SEARS, D.A., UDDEN, M.M. Howell-Jolly bodies: a brief historical review. Am J Med Sci, v.343, n.5, p.407-9. 2012.

SCOTT, K.L. et al. Biopreservation of red blood cells: past, present, and future. Transfus. Med. Rev, v.19, n.2, p.127-42. 2005.

STEINIGER, B.S. Human spleen microanatomy: why mice do not suffice. Immunology, v.145, n.3, p.334-46. 2015.

STOLZING, A. et al. Hydroxyethylstarch in cryopreservation - mechanisms, benefits and problems. Transfus. Apher. Sci, v.46, n.2, p.137-47. 2012.

TELEN, M.J. Red Blood Cell Surface adhesion molecules: their possible roles in normal human physiology and disease. Semin Hematol, v.37, n.2, p.13042. 2000.

VANCAUWENBERGHE, T. et al. Imaging of the spleen: what the clinician needs to know. Singapore Med J, v.56, n.3, p.133-44. 2015.

VOSKARIDOU, E., CHRISTOULAS, D., TERPOS, E. Sickle-cell disease and the heart: review of the current literature. Br J Haematol, v.157, n. 6, p.66473. 2012.

ZAGO, M.A., FALCÃO, R.P., PASQUINI, R. Tratado de Hematologia. 2ed. São Paulo (SP): Atheneu Press; 2013. 899p. 
APPENDICES 


\section{APPENDICES}

\subsection{Appendix I - Informed consent form for the collection and use of biological material}

Research Name: Splenic function and cellular adhesion events in Sickle Cell Anemia and in Hereditary Spherocytosis.

Researchers in charge: MSc Priscilla Carnavale Gomes Ferreira, PhD Ana Cristina Silva Pinto and PhD Dimas Tadeu Covas.

We would like to invite you to participate in this research project. This invitation is being made to a number of patients with Sickle Cell Anemia and with Hereditary Spherocytosis that undergo the clinical follow-up in the Hemoglobinopathies clinic at the Clinical Hospital $(\mathrm{HC})$ of the Ribeirão Preto Medical School of the University of São Paulo (FMRP-USP).

Participation is voluntary. To take part in the study, it is necessary to read this document carefully and listen to our explanations in case of doubts. If you are interested in participating, we will ask you to sign this document.

\section{Why will this research be performed?}

Sickle Cell Anemia and Hereditary Spherocytosis represent a major health problem in Brazil. They are hereditary diseases and therefore have no cure. The production of blood in our body occurs in the bone marrow. In certain special areas of the bone marrow, called erythroblastoid islands, there are important cells, called macrophages, responsible for making our red blood cells mature to circulate in blood vessels.

The spleen is an organ that has the important function of destroying the circulating old red blood cells, besides contributing also to the maturation of the red blood cells under specific conditions.

In patients with sickle cell disease and other Hemolytic Anemias, such as Hereditary Spherocytosis, the circulating blood cells, called reticulocytes, are immature and adhere abnormally to blood vessels, which leads to several serious side effects in patients. In this context, the spleen plays a fundamental role in the 
clearence of these abnormal cells, which gradually becomes overloaded and might eventually lose its function.

The purpose of our research is to investigate the role of the spleen in patients with Sickle Cell Anemia and Hereditary Spherocytosis with and without preserved splenic function in relation to the adhesive characteristic of reticulocytes and erythrocytes.

\section{Why is your participation important?}

For performing the research, it is necessary to analyze the blood of the patients with Sickle Cell Anemia and with Hereditary Spherocytosis and to compare them with the parameters that we intend to investigate.

This comparison serves to observe the real importance of the spleen in the clearance process of old and/or defective red blood cells, in the maturation of red blood cells and in the clinical evolution of the patient in general.

\section{How will this research be conducted?}

After you have agreed to participate in the study and have signed this Consent Form, we will collect a blood sample from your vein/your dependent's vein. For children with Sickle Cell Anemia, 5 blood collections (one collection each 3 months for a period of 1 year) will be required. For adults with Sickle Cell Anemia and for patients with Hereditary Spherocytosis, only one collection will be performed.

The collection of peripheral blood will be done by vein puncture of the arm after asepsis of the skin by the Hemocentro of Ribeirão Preto nursing team on the day of your return to the clinic. In addition, relevant clinical data will be extracted from your medical record in a second moment, preserving the confidentiality of it.

\section{How long will the research last?}

It will take the total of 3 years to complete the research and it may be necessary to collect new blood samples if the first one is not enough. 


\section{What risks can occur?}

Risks that may occur are: bruising at the site of venous punctures, pain and, more rarely, infection at the venipuncture site.

\section{What happens if you do not agree to participate?}

If you do not want to participate, your follow-up assistence in our clinic will continue the same, without any interference on your treatment.

\section{Are there any expenses or benefits in this study?}

There will be no expense and no cash gain. The only benefit will be to help us better understand the function of the spleen in your disease.

We affirm that all the data obtained will be kept in a confidential way and that the names of the participants will not be disclosed at any time.

For any questions about this research, get in touch with MSc. Priscilla Carnavale Gomes Ferreira by the telephone: (16) 2101-9300, extension: 9699.

I,

ID nationality , years

marital status , occupation address

authorize the collection of $10 \mathrm{~mL}$ (one tablespoon) of my blood / my dependente/'s blood, by venous puncture for research purposes on spleen function and cellular adhesion events in Sickle Cell Anemia and Hereditary Spherocytosis. I have been informed about the procedure and that the volume of blood withdrawn will not harm my health/ my dependent's health. I express my free consent to participate, being fully aware that there is no economic value to be received or to be paid for my participation. I have been also informed that the purpose of this research is to increase knowledge about the splenic role and the adhesive characteristic of reticulocytes in patients with hemoglobinopathies.

Ribeirão Preto, 
Signature of the patient

Signature of the researcher responsible

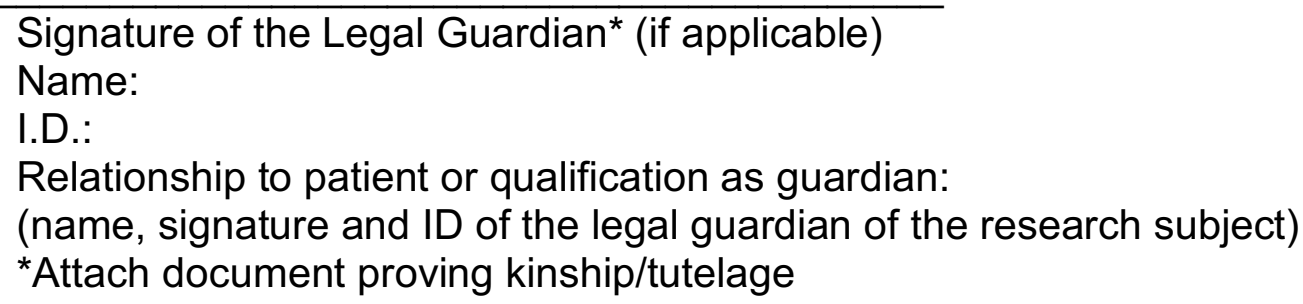

\subsection{Appendix II - Informed consent form for the storage of biological material}

We, PhD. Dimas Tadeu Covas and MSc., PhD student Priscilla Carnavale Gomes Ferreira, responsible for the Sample Bank entitled "SCA and HS peripheral blood samples storage", created at the Blood Center of Ribeirão Preto with the aim of storing samples of Sickle Cell Anemia and Hereditary Spherocytosis patients during the course of this project for research and scientific analysis purpose and for the repetition of an experimental trial, if it is necessary, concerning the research project "Splenic function and cellular adhesion events in Sickle Cell Anemia and in Hereditary Spherocytosis", we would like to ask for your permission to keep your blood sample/ your dependent's blood sample. Your participation is voluntary, having the freedom to accept or not that your sample be stored, without risk of any penalty or loss in your clinical treatment/ your dependent's clinical treatment. You also have the right to withdraw the consent given at any time.

This material will be obtained by collecting a blood sample from your vein / your dependent's by vein punture from the arm after local asepsis by the nursing team of the Blood Center of Ribeirão Preto on the day of your return to the clinic. After being collected, the samples will be frozen and kept in containers with liquid nitrogen at $-196^{\circ} \mathrm{C}$ in Blood Center of Ribeirão Preto's facilities.

We, PhD. Dimas Tadeu Covas and PhD student Priscilla Carnavale Gomes Ferreira, as responsible for the research, commit ourselves to identifying the samples and collected data in a way that guarantees its secrecy and its confidentiality. For that, your blood sample will be identified by means of alphanumeric sequential numbers. 
Regarding the blood collection, $10 \mathrm{~mL}$ (one tablespoon) of blood will be withdrawn through venous puncture for the research performance. The risks that may occur are bruising at the site of venous puncture, pain and, more rarely, infection at the vein puncture site. There is no expense and no cash gain. The only benefit is to help us better understand the spleen function in your disease.

We also require your personal information, so that it is possible to contact you later. Through this information, we guarantee to provide any information of your interest, in addition to receiving eventual benefits from the study with your biological material. We will also require your authorization, if it is necessary, for the disposal of the stored material at the study completion.

Data from the donor / the donor's legal guardian:

Name:

ID: $\mathrm{n}^{\circ}$ Telephone Address: Neighborhood , City

We request your signature (from the donor/ the donor's legal guardian), having received the information above, to confirm acceptance of your blood sample/ your dependent's blood sample storage at the Blood Center of Ribeirão Preto, under the responsibility of Dr. Dimas Tadeu Covas and PhD student Priscilla Carnavale Gomes Ferreira, for research and scientific analysis purposes. It is also stated that one copy of this document signed by both parts will be delivered to you.

Below, there is also the contact information of the researcher in charge, in case you have any questions later. For elucidation of ethical issues, you may also contact the Research Ethics Committee of HCFMRP-USP, which has approved this biorepository, at (16) 3602-2228.

\section{Responsible researcher's information:}

Name: Priscilla Carnavale Gomes Ferreira

Telephone: (16) 2101-9300, extension 9699.

Signature:

Data:

Participant's information (donor): 
Name:

Signature:

Data:

Donor's legal guardian's information (if applicable):

Name:

Signature:

Data:

ID:

Relationship to patient or qualification as guardian:

(name, signature and ID of the legal guardian of the research subject)

* Attach document proving kinship / tutelage

\subsection{Appendix III - Patients data collection form}

Name:

Clinical Hospital registration number:

Birth date:

Diagnosis: Age:

Indication of the disease:

Electrophoresis test:

Hydroxycarbamide (HC): yes ( ) no ( )

Beginning: Current dose:

Complications of the disease:

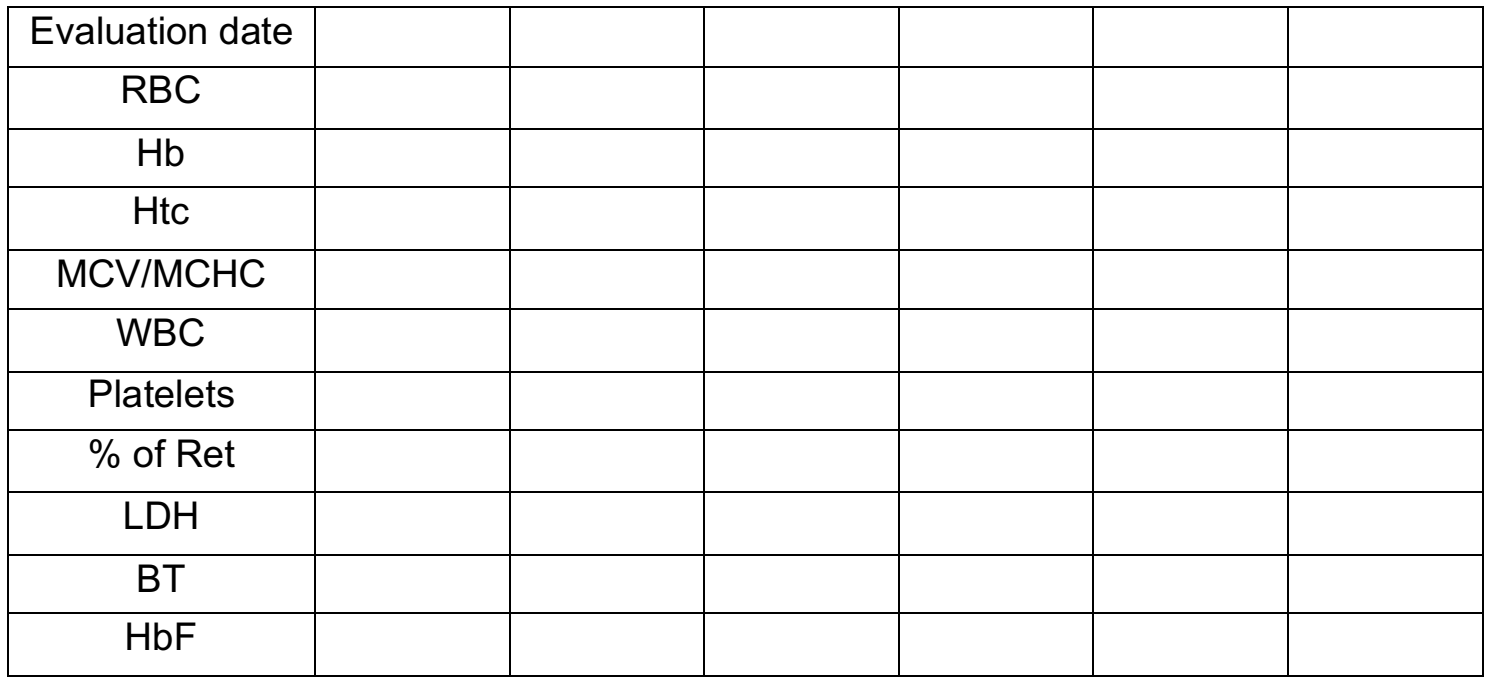

